\title{
3D cell-laden polymers to release bioactive products in the eye
}

Orive, Gorka; Santos-Vizcaino, Edorta; Pedraz, Jose Luis; Hernandez, Rosa Maria; Vela Ramirez, Julia E.; Dolatshahi-Pirouz, Alireza; Khademhosseini, Ali; Peppas, Nicholas A.; Emerich, Dwaine F.

Published in:

Progress in Retinal and Eye Research

Link to article, DOI:

10.1016/j.preteyeres.2018.10.002

Publication date:

2019

Document Version

Peer reviewed version

Link back to DTU Orbit

Citation (APA):

Orive, G., Santos-Vizcaino, E., Pedraz, J. L., Hernandez, R. M., Vela Ramirez, J. E., Dolatshahi-Pirouz, A., Khademhosseini, A., Peppas, N. A., \& Emerich, D. F. (2019). 3D cell-laden polymers to release bioactive products in the eye. Progress in Retinal and Eye Research, 68, 67-82.

https://doi.org/10.1016/j.preteyeres.2018.10.002

\section{General rights}

Copyright and moral rights for the publications made accessible in the public portal are retained by the authors and/or other copyright owners and it is a condition of accessing publications that users recognise and abide by the legal requirements associated with these rights.

- Users may download and print one copy of any publication from the public portal for the purpose of private study or research.

- You may not further distribute the material or use it for any profit-making activity or commercial gain

- You may freely distribute the URL identifying the publication in the public portal 


\section{Accepted Manuscript}

3D cell-laden polymers to release bioactive products in the eye

Gorka Orive, Edorta Santos-Vizcaino, Jose Luis Pedraz, Rosa Maria Hernandez, Julia E. Vela Ramirez, Alireza Dolatshahi-Pirouz, Ali Khademhosseini, Nicholas A. Peppas, Dwaine F. Emerich

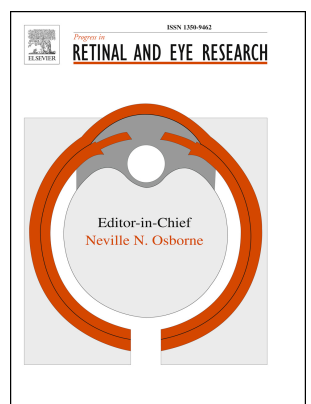

PII: S1350-9462(18)30025-9

DOI: 10.1016/j.preteyeres.2018.10.002

Reference: JPRR 737

To appear in: Progress in Retinal and Eye Research

Received Date: 26 March 2018

Revised Date: 2 October 2018

Accepted Date: 9 October 2018

Please cite this article as: Orive, G., Santos-Vizcaino, E., Pedraz, J.L., Hernandez, R.M., Vela Ramirez, J.E., Dolatshahi-Pirouz, A., Khademhosseini, A., Peppas, N.A., Emerich, D.F., 3D cell-laden polymers to release bioactive products in the eye, Progress in Retinal and Eye Research (2018), doi: https:// doi.org/10.1016/j.preteyeres.2018.10.002.

This is a PDF file of an unedited manuscript that has been accepted for publication. As a service to our customers we are providing this early version of the manuscript. The manuscript will undergo copyediting, typesetting, and review of the resulting proof before it is published in its final form. Please note that during the production process errors may be discovered which could affect the content, and all legal disclaimers that apply to the journal pertain. 
Title: 3D cell-laden polymers to release bioactive products in the eye

\author{
Authors: Gorka Orive ${ }^{1,2,3^{* \dagger}}$, Edorta Santos-Vizcaino ${ }^{1,2}$, Jose Luis Pedraz ${ }^{1,2}$, Rosa \\ Maria Hernandez ${ }^{1,2}$, Julia E. Vela Ramirez ${ }^{4}$, Alireza Dolatshahi-Pirouz, Ali \\ Khademhosseini $^{6,7,8,9}$, Nicholas A. Peppas ${ }^{10}$, Dwaine F. Emerich ${ }^{11 \dagger}$
}

1. NanoBioCel Group, Laboratory of Pharmaceutics, School of Pharmacy, University of the Basque Country UPV/EHU, Paseo de la Universidad 7, 01006 Vitoria-Gasteiz, Spain. Twitter: @gorka_orive

2. Biomedical Research Networking Centre in Bioengineering, Biomaterials and Nanomedicine (CIBER-BBN). Vitoria-Gasteiz, Spain.

3. University Institute for Regenerative Medicine and Oral Implantology - UIRMI (UPV/EHUFundación Eduardo Anitua), Vitoria, Spain; BTI Biotechnology Institute, Vitoria, Spain.

4. Department of Biomedical Engineering, The University of Texas at Austin, Austin, TX, USA; Institute for Biomaterials, Drug Delivery, and Regenerative Medicine, The University of Texas at Austin, Austin, TX, USA

5. Department of Micro- and Nanotechnology, Center for Nanomedicine and Theranostics, Technical University of Denmark, Kgs. Lyngby, 2800, Denmark.

6. Department of Bioengineering, Department of Chemical and Biomolecular Engineering, Henry Samueli School of Engineering and Applied Sciences, University of California-Los Angeles, Los Angeles, CA, USA

7. Center for Minimally Invasive Therapeutics (C-MIT), University of California-Los Angeles, Los Angeles, CA, USA

8. California NanoSystems Institute (CNSI), University of California-Los Angeles, Los Angeles, CA, USA.

9. Department of Radiology, David Geffen School of Medicine, University of California-Los Angeles, Los Angeles, CA, USA

10. Department of Biomedical Engineering, The University of Texas at Austin, Austin, TX, USA; Institute for Biomaterials, Drug Delivery, and Regenerative Medicine, The University of Texas at Austin, Austin, TX, USA; McKetta Department of Chemical Engineering, The University of Texas at Austin, Austin, TX, USA; Departments of Pediatrics and Surgery and Perioperative Care, Dell Medical School, The University of Texas at Austin, Austin, TX, USA; Division of Pharmaceutics, College of Pharmacy, The University of Texas at Austin, Austin, TX, USA.

11. Gloriana Therapeutics, inc, 225 Chapman St., Providence Rhode Island, USA.

* Corresponding Authors:

Gorka Orive. NanoBioCel Group, Laboratory of Pharmaceutics, School of Pharmacy, University of the Basque Country UPV/EHU, Paseo de la Universidad 7, VitoriaGasteiz 01006, Spain.E-mail: gorka.orive@ehu.eus_Twitter: @gorka_orive

Dwaine Emerich. NsGene, inc, 225 Chapman St., Providence Rhode Island, USA. Email: dwaine.emerich@gmail.com 


\section{Acknowledgements:}

The authors wish to thank projects SAF2016-76150-R from the Spanish Ministry of Economy, Industry and Competitiveness and PRGF 3.0 ELKARTEK KK-2017/00063 from the Basque Country Government and intellectual and technical assistance from the ICTS "NANBIOSIS", more specifically by the Drug Formulation Unit (U10) of the CIBER in Bioengineering, Biomaterials \& Nanomedicine (CIBER-BBN) at the University of the Basque Country (UPV/EHU). We also appreciate the support from the Basque Country Government (Grupos Consolidados, No ref: IT907-16).

\section{Conflict of Interests}

Authors declare no conflict of interests. 


\section{Content List}

1. Introduction

2. The immune privilege of the eye provides an opportunity for cell therapy

3. A brief history of encapsulated cell therapy

4. Micro- versus macroencapsulation

4.1 Microencapsulation

4.2 Macroencapsulation

5. Relevant properties of encapsulation devices

6. Delivery of neurotrophic and anti-angiogenic proteins

6.1 Delivery of CNTF from encapsulated cells: preclinical studies.

6.2 Clinical evaluation of encapsulated cell-based CNTF delivery in geographic atrophy, retinitis pigmentosa and glaucoma patients

6.3 Neuroprotection in the treatment of Macular Telangiectasia

7. Room for progress

8. Conclusion and future directions 


\begin{abstract}
Millions of people worldwide suffer from debilitating, progressive, and often permanent loss of vision without any viable treatment options. The complex physiological barriers of the eye contribute to the difficulty in developing novel therapies by limiting our ability to deliver therapeutics in a sustained and controlled manner; especially when attempting to deliver drugs to the posterior eye or trying to regenerate the diseased retina. Cell-based therapies offer a significant potential advancement in these situations. In particular, encapsulating, or immunoisolating, cells within implantable, semi-permeable membranes has emerged as a clinically viable means of delivering therapeutic molecules to the eye for indefinite periods of time. The optimization of encapsulation device designs is occurring together with refinements in biomaterials, genetic engineering, and stem-cell production, yielding, for the first time, the possibility of widespread therapeutic use of this technology. Here, we highlight the status of the most advanced and widely explored iteration of cell encapsulation with an eye toward translating the potential of this technological approach to the medical reality.
\end{abstract}

\title{
Keywords:
}

Cell therapy, encapsulation, ophthalmic diseases, drug delivery, encapsulated cell technology, protein. 


\section{Introduction}

The loss of vision, culminating in blindness, is one of the most prevalent and feared health conditions any person will ever face. According to the World Health Organization (2016) approximately 180 million people worldwide have visual impairments secondary to ophthalmic disease. Some of the most devastating examples are age-related progressive diseases of the posterior segment of the eye including agerelated macular degeneration (AMD), diabetic macular edema (DME), retinitis pigmentosa (RP) and diabetic retinopathy. These diseases impact tens of millions of people leading to vision impairment and blindness, reduced independence and limited normal activities. In developed nations, these diseases are the leading causes of vision loss. The societal and economic burden of these diseases is staggering. In the United States alone it has been estimated that $>40 \%$ of the population has some type of disease causing impaired vision with an annual economic impact of \$35 billion USD (National Center for Health Statistics, 2012).

While recent advances in biology are shedding light on the underlying nature of ocular diseases and have led to some new symptomatic treatments there are no cures or prosthetics that restore vision and the best hopes for patients is a slowing of disease progression. Unfortunately, the need for new and innovative approaches us becoming increasingly urgent as the aged population increases. While numerous factors contribute to the lack of therapeutics including limited understanding of disease mechanisms, significant patient heterogeneity, and our limited ability to detect early stage disease; much of the difficulty in treating and managing these diseases results from the unique anatomy and physiology of the eye that consists of a multilayered system that protects it from dangerous substances, microorganisms and toxins. These barriers, which are essential for maintaining vision, also limit the entry of potentially therapeutic drugs to the eye (Urtti, 2006). These barriers begin with the corneal and conjunctival epithelial layers that cover the ocular surface. The blood-aqueous barrier, consisting of the uveal capillary endothelia and ciliary epithelia, limits systemically administered drug access to the anterior segment, while the blood-retina barrier limits distribution from the circulating blood to the retina and vice versa. Two additional components of this system include the outer and inner blood-retina barriers that are formed by the retinal pigment epithelium (RPE) and the tight retinal capillary walls, respectively. 
Traditional routes of drug delivery to the eye include topical, oral, intravitreal and periocular delivery (Box 1). Topical application is well-suited for short-term delivery of drug solutions, suspensions or ointments but access beyond the anterior segment of the eye is limited (Lakhani et al., 2018). Systemic dosing using oral or intravenous delivery can be used to deliver drugs to the retina but this route suffers from several issues including peripheral metabolism/degradation, limited ability to cross the inner and outer blood-retinal barriers, and the need to use very high systemic doses which carry significant systemic toxicological potential (Awwad et al., 2017). Delivery of potential therapeutic proteins is further hampered by protein degradation and aggregation significantly limiting sustained delivery across these barriers (Awwad et al., 2017).

Periocular injection can enable drug delivery to the posterior segment by crossing the sclera, via the choroidal systemic circulation, or through the aqueous and vitreous humor (Waite et al., 2017). Direct intravitreal delivery provides the highest drug bioavailability to the retina because of the close association of the vitreous and retina but repeated intravitreal injections can lead to retinal hemorrhage/detachment, endophthalmitis and cataracts. Drug washout and clearance is also significant with these routes making sustained, long-term delivery in chronic diseases even more difficult to achieve (Martin, 2018). While difficult to accomplish, the value of sustained delivery is confirmed by the long-term drug delivery and efficacy achieved using the Retisert and Iluvian implant systems to deliver fluocinolone (Bertens et al., 2018).

This review focuses on an emerging concept for long-term drug delivery based on the use of living cells that are encapsulated within small, implantable capsules in the form of spheres or slender hollow fibers. Encapsulated cell therapy overcomes many of the fundamental obstacles of traditional approaches by combining the potency of de novo in situ synthesis of cell-derived molecules (including proteins and peptides) with the safety of an implantable and retrievable medical device. In this approach, cells are enclosed or "encapsulated" within a capsule that has a semipermeable outer wall or membrane that can be implanted directly into the desired region. The capsule wall morphology provides a pore structure that allows oxygen and nutrients to enter and nourish the cells while simultaneously providing a route for cell-secreted proteins, small molecules, antibodies, etc. to diffuse from the capsule and into the surrounding environment. 
Encapsulated cell systems have been used for many years to deliver molecules both systemically and into compartmentalized segments of the body including the brain and eye. While thousands of pre-clinical studies have confirmed the potential of this approach in multiple disease models, recent clinical studies have further demonstrated the clinical and medical translational reality of encapsulated cell technology. Within the visual system, locally implanted cells provide long-term release of potent drugs, proteins and peptides to specific areas including the vitreous or directly to the choroid, RPE, ganglion cells or photoreceptors of the neural retina. Here, we detail progress using these systems in both preclinical models and human diseases of visual impairment with an "eye" towards scaled and widespread clinical application.

\section{The immune privilege of the eye provides an opportunity for cell therapy}

The eye has a unique immunological privilege (Jiang et al., 1993). The limited exchange between the systemic system and the ocular environment restricts the entry of blood-borne factors and cells into the various chambers of the eye. From an evolutionary perspective, this immune privilege has developed to limit and control the intraocular expression of immunogenic inflammation which, if uncontrolled, could lead to serious functional and survival limitations. The immune privilege of the eye is based on a delicate balance of local and systemic mechanisms (Forrester et al., 2008; Perez and Caspi, 2015) that when altered may render the eye susceptible to immune action. For instance, in adult macular degeneration (AMD), glaucoma, chorioretinal disorder, autoimmune and diabetic retinopathy, immunity has a significant role in the progress of these pathologies (Nussenblatt et al., 2013; Perez and Caspi, 2015; Perez et al., 2013). Actions of the innate and adaptive immune systems play a critical role in both acute and chronic inflammatory responses (Benhar et al., 2012) with neutrophils and macrophages being involved in disease onset and T cell activation (Perez et al., 2013).

Both the anterior and posterior segments of the eye create unique environments which reduce and/or prevent immune defense mechanisms that could otherwise damage sensitive ocular tissue. This protection from "collateral damage" is based on the ocular tissue expression of immunosuppressive factors such as Qa-1, fas L, indolamine dioxidase (IDO), TGF- $\beta, \quad \alpha$-melano-stimulating hormone $(\alpha-\mathrm{MSH})$ and anticomplementary factors in aqueous humor (Cone et al., 2008; Niederkorn, 2002, 2006a; Stein-Streilein and Streilein, 2002). In addition, anterior chamber-associated immune 
deviation (ACAID) can be stimulated by ocular infection. For instance, subjects with virus-induced acute retinal necrosis do not generate cell-mediated immunity but do present circulating viral antibodies (Kezuka et al., 2001).

The immune privilege of the eye provides a valuable advantage for using living cellular systems to deliver molecules to the eye. Years of studies have certified that these properties, which are somewhat analogous to the central nervous system (Orive et al., 2010; Orive et al., 2009), lessen the chance for graft-destroying immune responses within the eye. As such, this unique microenvironment provides an optimal implant environment for the long-term implantation and functionality of cell-based medicines (Niederkorn, 2003; Taylor, 2016). In the case of encapsulated cells systems, immunological reactivity is even further reduced by the fact that the same porous structure that permits bi-directional flow also eliminates entry of damaging elements of the host immune system into the capsule.

Treating the chronic, progressive nature of many posterior segment disorders requires long-term and sustained treatment. Ideally, this treatment would circumvent the topical and systemic routes and apply the therapy directly into the vitreous in a minimally invasive, one-time procedure to target the retina. The pharmacokinetics of a variety of drugs shows that new approaches must be developed for the treatment of posterior segment disorders (Del Amo et al., 2017). Accordingly, various sustained-release gels, microparticles, nanoparticles and liposomes are being investigated for their ability to deliver drugs into the vitreous humor or periocular space (Table 1) in an extended manner.

The use of cell-based therapy to replace damaged retinal cells or to secrete a particular molecule or protein of interest is actively being investigated as a means of overcoming the traditional obstacles of targeted, long-term therapy (De Castro et al., 2005; Murua et al., 2007; Santos et al., 2013b). The retina is, in general an excellent target for evaluating cell therapies because of its relative immune privilege, but also because of it accessibility for surgical implantation and removal, and the ability to easily and repeatedly image and monitor the ongoing disease process and efficacy of any applied therapy. Numerous noninvasive techniques allow precise retinal examination in live animals and patients. The ability to quantify efficacy in subjects in a noninvasive manner over time is a major advantage and in the event of significant toxicity the eye can be removed without risk of life-threatening damage. Experimentally, eyes provide a 
perfect control group, as the contralateral, untreated eye can be compared with the intervention eye. Moreover, even though the eye itself is a complex organ, the number of cell types residing in the retina is relatively low allowing therapies to target replacement, repair, or protection of a single or low number of cell types such as pigmented epithelial cells, ganglion cells, or photoreceptors.

Given these considerations, we believe the risk-benefit ratio for the use of encapsulated cell therapy in ocular diseases is favorable. A partial list of reasonable criteria includes:

1. Degenerative ocular diseases are not life-threatening diseases in of themselves but they disproportionally impact a massive number of people worldwide with enormous impacts on quality of life, medical care and cost, and societal function.

2. The eye is a unique organ providing unparalleled access for real-time monitoring and evaluation of cell-based therapy that is otherwise not available in other tissue and organ systems.

3. Few effective treatments exist for degenerative ocular diseases and when therapies are available they tend to slow disease progression at best. Recently, LUXTURNA ${ }^{T M}, a$ one-time gene therapy for individuals with an inherited retinal disease due to mutations in both copies of the RPE65 gene has been approved. LUXTURNA improved functional vision, increasing participants' ability to perform activities of daily living.

4. The general approach of encapsulated cell therapy already has already been evaluated in clinical trials with demonstrated long-term (>5 years) safety.

5. The treatment has the potential to provide both symptomatic relief and also diseasemodifying benefits.

\section{A brief history of encapsulated cell therapy}

In the 1960's T.M.S. Chang introduced the concept of encapsulation as a strategy for immunoprotection of transplanted cells and tissues (Chang, 1964). This strategy, dubbed "artificial cells", incorporated the cells into spherical polymeric structures designed to ensure maximum surface/volume ratio and optimum protection. As originally conceived, cells are included in biocompatible polymeric matrices that allow the ingress of nutrients and oxygen diffusion to the encapsulated cells together with the 
outward diffusion of the cell-secreted product. This occurred while preventing the access of antibodies and immune cells (Figure 1) enabling the use of any type of allo- or xenograft. Thus, it became possible to recover the functionality of damaged tissues and organs or to simply act as a sustained release system of therapeutic factors. Over the next two decades, several experimental studies demonstrated the feasibility of these artificial cellular systems. In one of the most significant initial studies, Lim and Sun demonstrated that implanted encapsulated pancreatic islets controlled hyperglycemia in experimental diabetic animals (Lim and Sun, 1980).

Advances in genetics, biology and pharmaceutical technology have focused the therapeutic applications of cell encapsulation technology from a means of partial or total replacement of damaged organs (Limited; Limited; Technologies) (No da et al., 2014; Vegas et al., 2016b), to a strategy for the continuous and controlled release of a virtually unlimited variety of therapeutic molecules (Chang, 2005) across various chronic disorders (Desai and Shea, 2017; Emerich et al., 2014; Hashemi and Kalalinia, 2015; Zanin et al., 2012). The sustained delivery of proteins and peptides from encapsulated cells has become particularly attractive when compared to the direct encapsulation of purified peptides and proteins into sustained release polymers. In fact, entrapped cells synthesize and secrete active molecules as a function of physiological requirements and in "de novo" fashion. The latter is especially relevant due to the biological and physicochemical properties proteins must retain to preserve their function and potency (Shoichet and Winn, 2000). Today, there is a large body of evidence showing encapsulated cells can exert sustained biological effects and controlled activity ranging from months to years, regardless of the administration route or the used encapsulation device (Elliott et al., 2007; Sieving et al., 2006). Furthermore, some of the most relevant ideal requirements for cell-based devices are well-known as illustrated in Box 2.

The use of genetically-manipulated cells has played a pivotal role in the effort to achieve the goals of long-term, continuous and controlled administration of therapeutic products (Orive et al., 2014b). Numerous cell lines have been incorporated into biocompatible immobilization devices (Korsgren, 2017; Song et al., 2015; Tuch et al., 2011; Zanotti et al., 2013) to secrete hormones, neurotransmitters or growth factors over 
long periods of time and in controlled dosages not achievable with primary cells (Gonzalez-Pujana et al., 2017b). As such, cell encapsulation is being employed in the treatment of multiple pathologies such as diabetes (Basta et al., 2011; Tuch et al., 2009), intracerebral hemorrhage (AG; Heile and Brinker, 2011), and neurodegenerative diseases (Luo et al., 2013; Technologies; Technologies).

Advances in the scientific, manufacturing, and regulatory areas of cell encapsulation have resulted in the formation of several promising (Hunt et al., 2017; Liu et al., 2017; Song et al., 2015) biotechnological companies worldwide (Figure 2). Just to mention some examples, Viacyte (USA) is mainly based on the development of encapsulation devices using either islets or stem cells for the treatment of Diabetes (Viacyte.), while companies such as Living Cell Technologies (LCT, New Zealand, Australia) (Technologies.), and Neurotech (USA) (Neurotech.) offer systems based on different cell types for clinical evaluation in variety of therapeutic applications including Parkinson's disease, Alzheimer's disease, and several ophthalmic applications. Austrianova, in Singapore, offers encapsulation service in cellulose sulphate matrices, namely Cell-in-a-Box ${ }^{\circledR}$, in addition to a variety of assays on the encapsulated cell product, including pre-clinical tests, to demonstrate cell viability and function (Austrianova.). PharmaCyte (USA) uses the same technology registered by Austrianova to develop unique therapies for the treatment of various forms of cancer and both Type 1 and Type 2 diabetes (Biotech.). The dovetailing of continued academic research with industrial development will serve to further escalate the translation of cell encapsulation into clinical evaluation and product approval.

\section{Micro- versus macroencapsulation}

Two general types of devices are used for the immobilization of cells: microcapsules and macrocapsules. The latter, most frequently designed as hollow fibers, are composed of a semipermeable polymer that surrounds the encapsulated cells. Its size can range from a few millimeters to a few centimeters. In contrast, microcapsules are typically 100 to 700 microns in diameter. In microcapsules, the cells are incorporated into spherical polymer matrices coated with a semipermeable membrane that increases stability while regulating the permeability of the microcapsule. Microcapsules have an 
excellent surface/volume ratio, that favors the mass-transfer of oxygen into the capsule and that facilitates cell viability. Implanted macrocapsules also have adequate bidirectional diffusion but have the additional advantage that they are easier to remove if needed or desired. These 2 systems are detailed below.

\subsection{Microencapsulation}

There are four common strategies for microencapsulation: dual-core microspheres, polymer microsphere matrices, coated-microsphere matrices, and microcapsules. Each has particular advantages, depending on the targeted tissue (Olabisi, 2015). Microcapsules consist of a cell-laden matrix and a semipermeable coating. Hydrogels typically form the microcapsule core due to their high-water content and capacity to transition from a solution to gel (from sol to gel, gelation) in a cell-friendly manner. These matrices provide the cells with the physiological environment needed to maintain cell homeostasis and viability (Peppas et al., 1999; Vermonden et al., 2008). Hydrogels are known for creating three-dimensional structures with interconnected molecular meshes ranging from nano- to micrometers, that provide the optimal permeability required for the free diffusion of oxygen, nutrients, and growth factors. Their hydrophilicity renders them inert to protein or cell adsorption, thus reducing foreign body reactions (Gasperini et al., 2014). In microencapsulation, allogeneic (separate individuals of the same species) or xenogeneic (from different species) cells are protected from the host's immune system through separation from the immune components via the semipermeable membrane (Peppas et al., 2006). Furthermore, the flexibility and adaptability of microspheres allows them to be non-invasively implanted into almost any tissue. Finally, these particles can be readily fabricated and scaled-up, although some considerations should be taken into account. For example, one of the principal manufacturing challenges lies in translating laboratory-based techniques (maintained under aseptic, physiologic and mild conditions) to large scale, regulatorycompliant good manufacturing processes (GMP) amenable to clinical use.

So far, a large number of natural and synthetic polymers have been employed in the development of capsule matrices including alginate, agarose, chitosan, cellulose, collagen, poly(ethylene glycol) (PEG), polyurethane, and polyvinyl alcohol (PVA) (de Vos et al., 2014). Among them, alginate, a naturally occurring polysaccharide, is by far the most commonly used and studied option given its excellent biocompatibility, 
availability and unequaled, (mild, and cell friendly) gel forming capacity (Bayer et al., 2011; Lee and Mooney, 2012; Orive et al., 2014a; Peppas et al., 2000).

Without a doubt alginate microspheres can successfully encapsulate and immunoisolate cells (Mazumder et al., 2009) but the mechanical properties of these capsules still need to be improved. Only a few approaches have synthesized alginate microspheres with uniform size and good mechanical stability (Hernandez et al., 2010). One of the main drawbacks is that when using ionic crosslinking, the hydrogel core may be weakened by the exchange of calcium ions with other physiological ions. This weakening can in turn impact the function of encapsulated cells secondary to inadequate mechanical stimulation (i.e. mechanosensing). This issue can be quite difficult to resolve given that the viscoelastic properties of matrices (usually measured by a rheometer and/or texture analyzer) can be largely dependent on the cell/tissue to be encapsulated and the intended application. Some of the approaches that have been attempted to improve this include variation of molecular weight, guluronic acid/mannuronic acid (G/M) ratio, and the change of crosslinking strategies (i.e. covalent crosslinking). Thus, development of alginate-based composites has been explored to confer greater mechanical and thermal stability to alginate microparticles (Dandoy et al., 2013). These modifications still need to be further refined to optimize biocompatibility and the impact that these physicochemical changes have on their interactions with the body upon implantation (Tam et al., 2011). While there is an agreement that only alginate has been thoroughly qualified as safe for application in patients (de Vos et al., 2014) this biomaterial is still far from being ideal and the search continues for new materials and the design of new microcapsules with improved mechanical stability and guaranteed cell viability for longer periods of time (Santos et al., 2013b).

Microcapsules usually incorporate a polycation for the formation of the semipermeable membrane. Poly-L-lysine and poly-L-ornithine are the most extensively used polycations in the fabrication of the outer membrane (Simo et al., 2017). Thanks to the intrinsic characteristics of this membrane, nutrients and oxygen are able to penetrate the core, while the waste and therapeutic products of interest are released. In contrast, Tcell receptors and immunoglobulins are not able to interact with surface antigens on protected cells, and even access of the complement system is partially prevented by 
membrane pores; thereby avoiding or at least reducing their cytotoxic activity (Figure 3) (Chang and Prakash, 1998).

The outer coatings are primarily responsible for mechanical properties of microcapsules, providing resistance to either pressures exerted by the nearby tissues or pressures generated by enclosed cells because of possible overgrowth. This is of paramount importance since it is a priority that the capsules prevent the leakage of the immobilized cells and avoid the risk of uncontrolled extracapsular growth.

The outer coatings are primarily responsible for mechanical properties of microcapsules, providing resistance to either pressures exerted by the nearby tissues, which are generally reproduced in laboratory by a texture analyzer (compression assay), or pressures generated by enclosed cells because of overgrowth, the latter being usually assessed by swelling/explosion assays (osmotic shock test) in vitro. This is of paramount importance since it is a priority that capsules prevent the leakage of the immobilized cells and avoid the risk of uncontrolled growth in surrounding host's tissues. Strikingly, to date there are no standardized parameters to stick to when it comes to focusing on different applications, and sometimes this issue remains largely overlooked (Paredes Juarez et al., 2014). To address this issue, several authors have proposed key parameters to properly design and fabricate the cell-loaded capsules. For example, Lacik studied the rupture load necessary to succeed in intraperitoneal implantations with microcapsules made by different biomaterials, concluding that the range of few to tens of grams/capsule was enough to resist those in vivo conditions (Lacik et al., 1998; Wang et al., 1997) .Moreover, most authors agree that implantation in intraperitoneal cavity necessarily involves higher resistance to rupture than other routes such as striatum or subcutaneous space. On the other hand, the minimum mechanical stability requirements for intravitreal injection are still to be elucidated. As additional concern, going from small to larger mammals, where shear and compressing forces are higher, would demand a proper adaptation of mechanical properties. ParedesJuares and colleagues stated that microcapsules withstanding an $8 \mathrm{~g}$ force were able to complete the whole lifespan of rats ( 2 years approximately), but failed in pigs (Paredes Juarez et al., 2014).

The size of microparticles has been a major concern during the last decade. Elaborating microcapsules of reduced size means opening a new horizon of possibilities for their application. Diseases of the CNS or the eye are clear examples of this. Applying 
genetically modified, immunoisolated cells in places such as the spine, cerebral cortex, striatum or ocular retina is an ambitious challenge, but sound steps have been made lately. For example, flow focusing technology has been harnessed to produce highly monodisperse alginate-poly-L-lysine-alginate $($ APA) microcapsules $(\approx 100 \mu \mathrm{m})$ to minimize local damage while delivering maximal, low variability capsule numbers to the intravitreous space. Encapsulated mouse-derived $\mathrm{C}_{2} \mathrm{C}_{12}$ myoblasts implanted in the rat vitreous, remained viable for at least 3 weeks (Figure 4) (Santos et al., 2012). Although this duration is still far from being ideal, it proves the feasibility of this therapy, even with a xenogeneic cell source. Further optimization in cell requirements (e.g. accommodation to low oxygen levels) and microcapsule configuration (e.g. permeability) will probably translate into more optimistic results. Fabrication of conformal coatings may represent another effective encapsulation design (Gattas-Asfura and Stabler, 2013; Wilson et al., 2011). Here, a thin, full and regular shell adapted to the geometry of the cellular content is created (Tomei et al., 2014). In fact, constant improvements in microfluidic fabrication methods are bringing the opportunity to obtain relatively homogeneous beads of sub-50 $\mu \mathrm{m}$ size at higher production rates (Akbari et al., 2017).

\subsection{Macroencapsulation}

Although the term macroencapsulation refers to a family of devices including flat-sheets (Lathuiliere et al., 2016), ßAir ${ }^{\circledR}$ (Ludwig et al., 2012; Neufeld et al., 2013), Encaptra® (Agulnick et al., 2015) or TheraCyte ${ }^{\mathrm{TM}}$ (Kumagai-Braesch et al., 2013), among others; the majority of work is focused on hollow fibers-like devices (Figure 5). Despite not having the same volume of published basic research backing-up its technological development, hollow fibers represent a significant portion of the clinical trials in the field (Olabisi, 2015). The main advantage of macrocapsules is that once the therapy is completed and/or in case the treatment requires to be halted, the device can be easily removed from the implanted tissue. The possibility of retrieving the implanted cells mitigates some major biosafety concerns, including the uncontrolled proliferation of enclosed cells or any undesired adverse effect (Lathuiliere et al., 2015). Moreover, it is worth noting that hollow fibers can be adapted for implantation into the vitreous, the subcutaneous space and the always difficult to reach CNS, both intrathecally and intraparenchymally (Lathuiliere et al., 2015). 
A typical hollow fiber structure consists of an outer sealed, cylindrical and permselective wall composed of thermoplastic polymers such as polyethersulfone (PES) or poly(acrylonitrile-vinylchloride) (PAN-PVC), with a molecular weight cut-off (MWCO) of 60-100 KDa (Olabisi, 2015; Uludag et al., 2000). Besides regulating the passive diffusion of molecules and preventing access of humoral and cellular immune components across the capsule, the membranes must have the necessary mechanical properties to bear the shear stress exerted by the target tissue during the implantation, during residence of the device in vivo, and during explantation. Indeed, hollow fibers tend to bend and curve, which may result in graft failure (Lathuiliere et al., 2015). In order to overcome such drawbacks, the devices may be reinforced by inclusion of titanium coils (Schwenter et al., 2011), or addition of thermoplastic meshes (Josephs et al., 1999; Lathuiliere et al., 2014b; Lathuiliere et al., 2015).

The inner part of a typical hollow fiber device consists of a polyvinyl alcohol (PVA), polyethylene terephthalate (PET) or PVC matrix providing an adherent scaffold for the encapsulated cells. Additional options for the internal scaffolding include natural polymers like alginate (Cornolti et al., 2009) or collagen (Li et al., 2000). Because the size and geometry of the device limits the cell content, and thus the final secretion/dosing of active compounds a balance must be maintained between a high enough cellular density to achieve therapeutic dosing (Lathuiliere et al., 2014b), adequate oxygen and nutrient diffusion, and prevention of excessive proliferation/aggregation, cellular necrosis, and the release of the so-called damageassociated molecular patterns (DAMPs) (Lathuiliere et al., 2015). Recent advances in the development of genetically modified stable cell lines capable of secreting high levels of therapeutic factors play an important role in a suitable strategy to achieve these goals (Lathuiliere et al., 2014a).

\section{Most relevant properties of encapsulation devices}

The ultimate and ideal drug delivery system should provide an effective concentration of the therapeutic compound at the target site for an extended period of time; all while minimizing systemic exposure. At the same time, the success of a biomaterial-based, implantable drug delivery system is highly dependent on the capacity to customize and 
tune its building-blocks to achieve appropriate biocompatibility, physicochemical properties and desired biological responses. The chemical composition, pore size, and the size of these devices are critical for the efficacious biomolecule transport between the encapsulated cells and the target environment.

In this sense, cell encapsulation offers several advantages as drug delivery system. (1) First, encapsulated engineered cells may act as customized factories producing the desired therapeutic factor de novo and in a sustained fashion. This provides chemical stability and higher efficiency when compared to direct drug administration and/or drug encapsulation. (2) The immobilization genetically-modified cellsis particularly attractive, since one administration ensures the effectiveness of treatment for several months to years. (3) Cell encapsulation allows the protection of the inner cell content from both mechanical stress and the host's immune response. Thus, chronic administration of immunosupressants can be eliminated, further improving quality of life. (4) An important advantage in comparison with in vivo gene therapy is that this technology does not modify the host's genome, enhancing its biosafety (5) There is a wide range of cell sources available for immobilization, from freshly isolated mesenchymal stromal cells, to multiple bioengineered cell lines, and stem cells.

In the last decade, much effort has been placed on studying and improving the biocompatibility of encapsulating materials to ensure long-term functionality. The use of clinical-grade biopolymers is fundamental. It is well documented that raw alginates can induce lymphocyte stimulation, pro-inflammatory cytokine activation and eventual fibrosis. To prevent such a scenario, the use of commercially available ultra-purified, "clinical-grade" alginate has been established as the minimum criteria to reduce the foreign body reaction to microcapsules (Basta and Calafiore, 2011; Calafiore and Basta, 2014; Kim et al., 2013). Indeed, this alginate does not elicit any immune response when injected subcutaneously in mice or when assayed in a human whole blood model (Gravastrand et al., 2017; Lee and Mooney, 2012; Orning et al., 2016; Rokstad et al., 2011). Foreign body responses may be even further mitigated by chemical modification of alginates with triazole-thiomorpholine dioxide (TMTD). The latter has been proposed as a valuable strategy to achieve a better biocompatibility (Vegas et al., 2016a; Vegas et al., 2016b), though further independent studies should certify this hypothesis. Of note, while these same criteria apply to macrocapsules, recent clinical trials conducted by 
Neurotech, inc. have confirmed the biocompatibility and retrievability of macroencapsulated CNTF-secreting cells (see below for additional details).

Membrane permeability is another pivotal parameter for the design and fabrication of cell-laden devices. The semi-permeable barrier must support cellular metabolism, proliferation, differentiation and cellular homeostasis (de Vos et al., 2002; Uludag et al., 2000). The viability and function of encapsulated cells and permeability of microcapsules has been correlated for many years. However, this correlation depends on several factors that are still poorly understood and it is challenging to define appropriate permeability requirements as they relate t ospecific cell types (Rokstad et al., 2014). However, there is a wide consensus that, for most cases, the ideal molecular mass cutoff (MWCO) should be around 70 kDa (Orive et al., 2014a; Uludag et al., 2000).

Not all cell types are likely to perform in the Intravitreal space as it presents an uncommon hypoxic environment to encapsulated cells (Niederkorn, 2006b). For this reason, primary cells might be suboptimal choises given their limited lifespan and the fact that they are harder to expand or modify genetically. Cell lines could in principle be immortalized and engineered to be resistant to hypoxia and nutrient deprivation but these cell lines may also show undesirable behaviour, giving rise to erratic and uncontrollable responses. These considerations seem to have been primary in the choice of the immortalized, human retinal pigment epithelial cell line (ARPE-19) used by Neurotech, inc. in their clinical trials. The ARPE-19 line, originally derived from the retina of a donor patient is contact inhibited, amenable to genetic modification, and performs well post implantation. Stem cells are progressively gaining prominence due to their immune-privileged properties and plasticity (Attia et al., 2014; Goren et al., 2010). Among these cells, mesenchymal stem cells (MSCs), derived from bone marrow, adipose tissue, dental pulp or umbilical cord blood, together with neural stem cells (NSCs) represent interesting options to build cell encapsulation technologies for therapeutic aims in eye. Both MSCs and NCSs exert neuroprotection and axon regeneration of retinal cells, including Retinal Ganglion Cells, by secreting neurotrophic factors such as nerve growth factor (NGF), brain-derived neurotrophic factor (BDNF), glial cell-derived neurotrophic factor (GDNF) or ciliary neurotrophic factor (CNTF) (Mead et al., 2015). 
Optimal device performance requires understanding and regulating the biology of the encapsulated cells. Cell-matrix interactions play a key role in this aspect of cell encapsulation. Biologically inert polymers can be biofunctionalized with Arg-Gly-Asp (RGD) (Santos et al., 2014; Yu et al., 2010) and many other adhesion sequences (Llacua et al., 2018; Nakaoka et al., 2013). RGD sequences are found in natural adhesion proteins of the extracellular matrix including fibronectin, vitronectin or fibrinogen. The incorporation of these sequences into the otherwise inert matrices allows cell adhesion through the integrins, making possible focal contacts that act as mechanosensors, transmitting regulatory signals to promote cell survival and enhance long-term functionality (Cipitria and Salmeron-Sanchez, 2017; Lv et al., 2015; Walters and Gentleman, 2015).

The mechanical properties of device matrices can also affect cellular behavior, depending on the type of cell. Therefore, cell behavior can be further regulated by tuning the composition of the system (Huebsch et al., 2010; Trappmann et al., 2012). This can be achieved by varying the chain length of the polymers, component ratios or by adjusting its concentration (Chaudhuri et al., 2016; Wilson et al., 2014). It is also possible to adjust the crosslinker ratio (Trappmann et al., 2012) or to use crosslinking agents with different affinities $\left(\mathrm{Ba}^{2+}>\mathrm{Sr}^{2+}>\mathrm{Ca}^{2+}\right)$ that confer unique physical properties to the systems (Chan et al., 2011). The choice of osmolarity adjusting agents significantly contributes to mechanical stability and the regulation of cell responses, for example, by exerting control over the proliferation rate of the cells. Tailoring of the physicochemical properties of the developed system for the target cell type is important for its compatibility and functionality. which at the same time provides a safer and more predictable delivery of peptides/proteins (Gonzalez-Pujana et al., 2017a)

Finally, biosafety represents, undoubtedly, a paramount concern for this biotechnological approach in its path towards clinical use (Santos et al., 2013b). Towards this end, genetic procedures are being developed to facilitate monitoring and regulation of implanted cell-based devices. For example, reporter/biosafety genes such as $\mathrm{pSFG}_{\mathrm{NES}} \mathrm{TGL}$ vector, which codes for reporter genes of herpes simplex virus thymine kinase Type 1 (HSV1-TK), fluorescent green protein (GFP) and luciferase (Luc). have been introduced in the genome of encapsulated cells (Catena et al., 2010; Deglon et al., 1996; Santos et al., 2013a). Thus, it is possible to know the exact location and activity 
of the encapsulated cells in a non-invasive and real time manner (Catena et al., 2010). Other possibilities include inducing cellular apoptosis to inactivate the implanted cells via intravitreal injection of ganciclovir (Deglon et al., 1996; Santos et al., 2013a).

\section{Delivery of neurotrophic and anti-angiogenic proteins}

Neurotrophic factors play key roles in the repair and protection of normal neuronal function in adult organisms and in the survival and differentiation of neurons during development, following brain injury, and in neurodegenerative diseases (Skinner et al., 2009). Several trophic signaling molecules provide neuroprotection to retinal neurons in vivo and in vitro including basic fibroblast growth factor (bFGF), neurotrophic cytokines, nerve growth factor (NGF) and brain-derived neurotrophic factor (BDNF), pigment-epithelium-derived factor (PEDF), and the neuropoietic cytokine ciliary neurotrophic factor (CNTF). Ciliary neurotrophic factor is one of the most studied molecules and has been consistently been shown to rescue photoreceptors and retinal ganglion cells from genetic and environmental insult.

Like other potentially therapeutic, neuroprotective cytokines and proteins, CNTF cannot be effectively delivered via direct injection as it suffers from a short half-life and potential local toxicity secondary to the high dose requirements needed to acheive efficacy. To overcome these limitations, gene and cell-based therapies have been developed both pre-clinically and clinically. Direct replacemnt of defective genes provides the possibility of replacing a single defective gene within a specific cell type. While appealing, this approach is limited given that there is enough diversity of ocular cell types to require multiple therapeutic interventions to be effective. A second general approach involves manipualting the host cellular machinery to produce a therapeutic molecule or knock-down a defective gene. While promising, gene therapy requires the therapy to be delivered directly to the target site, which can require subretinal injections and associated retinal detachment. The risk of immunological responses to the treatment is limited but it is not possible to regulate or discontinue expression of the trophic factor once the virus is injected. The uptake and efficiency of the virus in human cells may also differ from that of animal models. 
Stem cells can be differentiated and injected to repopulate damaged retinal cells. Stem cells can also be engineered to produce trophic factors and can then be injected directly into the target site. While inherently appealing, stem cells may produce additional active factors beyond those desired, and once injected, stem cells may migrate; raising safety concerns. The limitations to this approach are similar to those seen in gene therapy. Patients' bodies may reject the stem cells, and there is an overall lack of ability to control the stem cells once they are injected.

Angiogenesis plays an important role in normal physiological process but pathological angiogenesis occurs in several eye disorders such as age-related wet macular degeneration and diabetic retinopathy. This abberant neovascularization involves the growth of new, abnormal blood vessels and is promoted by VEGF. Anti-VEGF injections effectively improve vision in patients but their use could be improved by eliminating the need for frequent injections and assoiciated heavy treatment burden. A long-term, continuous therapy with a low treatment burden remains a clear unmet need in wet AMD treatment. The intraocular inhibition of the action of VEGF has been recently attempted in clinical trials by Neurotech using the NT-503 device (see section below) (Guerrero-Naranjo et al., 2013). A similar strategy has also been approached in preliminary studies using microcapsules containing entrapped cells engineered to produce the soluble receptor of VEGF (KDRs). In this approach, murine cells were able to survive at least 3 weeks in the vitreous of rats (Santos et al., 2012). Anti-angiogenic factors released from encapsulated cells have also been investigated for their antitumor activity. By using endostating-secreting biosystems, significant enhancement of survival was obtained in a BT4C brain tumor model (Read et al., 2001). Later studies confirmed that this therapy reduced tumor vascularization, although tumor growth was not reduced in that study (Kleinschmidt et al., 2011).

\subsection{Delivery of Ciliary Neurotrophic Factor from encapsulated cells: preclinical studies.}

CNTF has shown to be effective in retarding photoreceptor neuron loss in animal models of retinal degeneration, including environmental light stress and genetic dysfunction models with resulting phenotypes similar to retinitis pigmentosa and geographic atrophy (Liu et al., 1999; Tao et al., 2002). The most developed iteration of 
CNTF therapy using encapsulated cells has been developed by Neurotech. Their approach uses a macro-encapsulation device with a polyethersulfone external membrane (NT-501) that contains an immortalized, human retinal pigment epithelial cell line (ARPE-19) that is genetically engineered to secrete therapeutic proteins such as CNTF (NT-501) or anti-VEGF receptor (NT-503) at a regulated delivery rate (Kauper and Nystuen, 2017). As observed with other cell lines including myoblasts and fibroblasts (De Castro et al., 2005), ARPE-19 is easily amenable to genetic engineering by stable expression of transgene vectors and it is biologically stable, a very relevant property compared to other unstable cell sources immobilized in encapsulation devices (Orive et al., 2001). The device has been constructed using a semi-permeable polymer outer membrane, medical-grade sealant and a titanium anchor at one end of each device to facilitate suturing to the sclera following implant through the pars plana and into the vitreous of the eye.

From a structural perspective, these devices each use an internal polyethylene terephthalate (PET) yarn scaffold. The membrane, which is porous and manufactured using traditional polymer phase-inversion techniques, allows oxygen and nutrients in the vitreous to freely diffuse inward, and allows therapeutics to freely diffuse outward as well as it resists protein fouling by serum proteins such as those found in the vitreous (Singh et al., 2012). The potency of this system is supported by evidence showing the benefits of CNTF as a potential therapeutic for retinal degenerative diseases (Bok et al., 2002; Rhee et al., 2013) as it reduces photoreceptor loss associated with degeneration of the cells of the outer retina. Neurotech demonstrated that encapsulated CNTFproducing cells protected photoreceptors in the outer nuclear layer (ONL) of experimental rats and dogs. In the rhodopsin deficient rat model of retinitis pigmentosa (RP), intravitreally placed CNTF devices were compared to identical control devices containing non-modified ARPE-19 cells. While control animals exhibited 1-2 rows of photoreceptors, the CNTF-treated animals showed a significantly higher (5-6) rows of these same photoreceptors. These data were confirmed in the rcdl dog model of RP where CNTF devices also conferred a protective effect on ONL photoreceptors. The 1 $\mathrm{cm}$ long devices were implanted into the vitreous when the dogs were 7 weeks old and remained in vivo for an additional 7 weeks. The contralateral eye was untreated for control purposes. Results revealed that each treated eye had significantly more photoreceptors and the cells in the capsules remained viable and densely distributed 
throughout. Importantly, the protection of photoreceptors was dose-dependent with minimum protection observed at $\mathrm{CNTF}$ doses of 0.2 to $1.0 \mathrm{ng} /$ day relative to that achieved at higher doses (Figure 6) (Tao et al., 2002).

\subsection{Clinical evaluation of CNTF Delivery from ECT in geographic atrophy, retinitis pigmentosa and glaucoma patients}

Based on encouraging preclinical data, Neurotech conducted a Phase 2 clinical trial (Pharmaceuticals) to test its CNTF implant, designated as NT-501, in patients with RP and geographic atrophy (GA) (Zhang et al., 2011). Patients treated with the high dose NT-501 implant (approximately $20 \mathrm{ng}$ /day), exhibited a statistically significant increase in macular volume between 4 and 12 months as determined using optical coherence tomography. A trend towards visual stabilization was observed and a subgroup analysis of high dose patients that started the trial with a visual acuity of 20/63 or better revealed a modest but a significant improvement over the 12-month treatment period compared to the control group.

Critically, after removal 2 years later, the devices continued to release CNTF (Figure 7). Histological evaluation of the devices confirmed that the continued release was associated with viable cells. The company followed these results with a report of good viability and secretion from explanted clinical devices after 5.5 years. In another study, two patients with RP and one with Usher syndrome type 2 who participated in a Phase 2 clinical trial (Pharmaceuticals) received CNTF implants in one eye and sham surgery in the contralateral eye (Talcott et al., 2011). No changes were noted in visual acuity, visual field sensitivity, or electroretinography responses in either eye of the three patients over 24 months. The outer retinal layers were significantly thicker in CNTFtreated eyes than in sham-treated eyes and cone spacing and density was increased in the CNTF treated versus the control eyes (Figure 8). Collectively, these data confirm long-term, sustained deliver of CNTF to the vitreous with the potential to protect retinal morphology. Data recovered from these initial clinical trials suggested that sustained intraocular delivery of $\mathrm{CNTF}$ has the potential to protect retina from degeneration in humans and further provides evidence for the therapeutic potential of CNTF delivery by encapsulated cell technology. 
Glaucoma is another indication that might be amenable to treatment with CNTF. For more than 150 years, the only proven treatment for glaucoma has been the reduction of intraocular pressure with drugs or surgical approaches (Liebmann and Cioffi, 2017). Today, the ultimate goal in glaucoma research is the identification of treatment interventions that directly target neuronal health and survival thereby treating the underlying damage to the retina and optic nerve. Long-term treatment with CNTF could beneficially impact the pathology of glaucoma. CNTF levels are reduced in the aqueous humor and lacrimal fluid of patients with primary open-angle glaucoma (Shpak et al., 2017). CNTF is also released by retinal glial cells in response to injury and it promotes retinal ganglion cell survival. A Phase I clinical study involving 11 patients with primary open-angle glaucoma was initiated in 2012 to evaluate safety, neuroprotection and neuroenhancement of CNTF-releasing NT-501 CNTF implants (Goldberg). Eighteen months of CNTF delivery was associated with maintenance of visual field and with regenerated retinal nerve fiber layers relative to untreated control eyes. A Phase 2 trial was initiated to confirm these findings, but results are currently unavailable.

\subsection{Neuroprotection in the Treatment of Macular Telangiectasia}

Given the involvement of CNTF in neuroprotection and suggestions of possible therapeutic benefit in retinal diseases, NT-501 delivery of CNTF is being investigated in macular telangiectasia (MT) patients. NT-501 CNTF devices were implanted into the vitreous of a single eye in patients in an initial Phase 1 trial (Pharmaceuticals). After 4 years, a 5 letter improvement in visual acuity was observed in the treated eye suggesting that NT-501 treatment slowed the progression of vision loss. The data further showed that progression of the inner segment -outer segment (IS/OS) break was reduced by $43 \%$ indicating a reduction in photoreceptor atrophy. Based on these data, a Phase 2 multi-center, controlled study of NT-501 treatment for MT was initiated (Pharmaceuticals). In 2017, Neurotech reported the results of the 67 patient study. After 24 months of CNTF treatment, there was significantly less photoreceptor loss versus sham. The area of ellipsoid zone break increased significantly by $0.213 \mathrm{~mm}^{2}$ in sham eyes compared to $0.148 \mathrm{~mm}^{2}$ in treated eyes. Neurotech also reported that macular thickness and the proportion of eyes with a $35 \%$ or more increase from baseline in the ellipsoid zone was significantly reduced following CNTF. 


\section{Room for progress}

Significant progress has been achieved in the delivery of potential therapeutics to the eye and cell encapsulated-based protein delivery is one of the more promising approaches with notable demonstrations of long-term and reasonably stable protein delivery both in pre-clinical and clinical studies. Still, there are critical issues that need to be overcome to optimize use of this therapeutic approach. First, while device-related adverse events have been uncommon to date, more detailed studies will be needed to determine the risk/benefit as related to possible events including vitreal leakage and retinal damage and/or detachment. The possibility of inflammatory responses with associated increases in intra-ocular pressure, possible corneal trauma, cataract formation, local scarring, and changes in fluid drainage and reabsorption all need to be carefully considered. Second, genetically-modified cells will likely continue to be used in the future. To date, no obvious issues have arisen, but larger and more lengthy studies will be needed to ensure that the vectors and transfection techniques used are stable and without mutagenicity. Third, degenerative diseases will probably require life-long therapy. A significant challenge will be titrating an effective therapeutic dose of the desired agent in the face of ongoing degeneration. Trials to date have delivered low levels of factors such as CNTF for several years but it remains unknown whether the molecule (e.g. CNTF) was effectively tested or whether further dose-escalation could yield better results. This issue will not be related to only CNTF as being able to control and test various doses of single or multiple compounds from encapsulated cells over prolonged times to achieve controlled and predictable dosing remains a formidable challenge. A fourth issue is related to the choice of molecule to test. The two fundamental and overarching issues in the topic are how to deliver the desired molecule and which molecule to deliver. Assuming that encapsulated cell technologies can fulfill the first goal (and will presumably only become more reliable) the choice of molecule remains a complex and largely open question. One example of this is the use of NT-503. A recent Phase 2 trial of a soluble anti-VEGF receptor protein was discontinued. The Neurotech, inc website stated "the study was stopped due to a larger than anticipated number of patients requiring rescue medication in the treatment arm. ECT was well tolerated for the duration of the trial and there was no observed safety signal that contributed to the decision to discontinue the trial." Few details are available and it 
remains unclear if the dosage was inadequate, if the study design and patient inclusion could have been optimized, or if the molecule is simply ineffective in this disease. Nonetheless, as pointed out by Kauper and Nysteun (Kauper, K., Nystuen, A., 2017) patients demonstrated equivalent or improved stability in visual acuity relative to controls despite requiring more supplemental injections of aflibercept than planned. The authors concluded that increasing the amount of soluble VEGF receptor protein should be evaluated as logical next step in developing this approach. These complexities serve to highlight both the potential of this approach and the amount of research, clinical evaluation, time, and expense that will be needed to fully answer these questions.

\section{Conclusion and future directions}

Retinal diseases such as macular degeneration, diabetic macular edema, retinitis pigmentosa, glaucoma and macular telangiectasia are extremely common and each of them presents a unique etiological and pathological spectrum. This heterogeneity has played a limiting factor in the development of novel therapeutics. Another major limiting factor has been the development of drug delivery systems capable of providing sustained, long-term delivery to the posterior segment of the eye via the physiological barriers dictated by ocular anatomy. Several approaches are under continued development to optimize drug delivery to the eye including direct injections, gene therapy approaches, and cell-based delivery using stem cells. Each have advantages but are restrained by practical and technical issues that limit their further development and widespread use. Direct injections are cumbersome, invasive, and require frequent, perhaps life-long treatments. Pump technologies have become increasingly useful for sustained delivery but are not practical for the eye. In gene therapy, a viral vector containing the gene that expresses the trophic factor is injected directly into the target site. If successful, the patient's cells to produce the desired factor. This approach can achieve high levels of localized production but is limited by difficulties regulating or discontinuing expression of the factor once the virus is injected. Finally, stem cells can be engineered and injected into the desired site easily. Stem cells may produce additional active factors beyond those intended, and the cells may migrate. With both gene therapy and stem cell approaches, it is difficult to discontinue the treatment of refine the dosing as needed. 
In this review, we discussed the development of a delivery system based on implanting cells that have been encapsulated in a polymer membrane before implantation. The pores of the membrane are sufficiently large to allow molecules to cross the membrane and enter the surrounding host tissue, but small enough to protect the encapsulated cells from host recognition and possible immune destruction. Encapsulated cell therapy provides a targeted, continuous, de novo synthesized source of high levels of factors including small molecules, proteins, and antibodies that can be distributed throughout the target site. As such, this therapeutic technology platform combines the potency of de novo, in situ synthesis of cell-derived factors with the safety of an implantable, biocompatible, and retrievable medical device. Encapsulated cells remain viable and continuously deliver factors to the surrounding tissue following implantation because the capsule is constructed such that oxygen and nutrients can enter to nourish the encapsulated cells. Immunological reactions of the encapsulated cells are obviated because the semipermeable membrane prevents the host immune system from gaining access to cells; thereby preventing their rejection. By using human cells as delivery vehicle, the chances of immunological reactions can be even further reduced. An additional advantage is that the capsule can be removed and/or replaced if necessary or desired. These advantages have been confirmed to a large extent in recent clinical trials where continued CNTF secretion was confirmed following implantation directly into the vitreous.

While we are suggesting that encapsulated cell technologies hold the greatest current opportunity to provide long-term, perhaps permanent delivery, of efficacious molecules, it is possible that this approach will ultimately be a part of a sophisticated multilayered approach to treating retinal diseases. As it currently stands, the most advanced iterations use the delivery of trophic factors such as CNTF. This approach is only useful during a portion of the degenerative process. Early, pre-symptomatic treatment is currently not possible without clear cut genetic markers and intervention too late in the process is likely to be ineffective due to the lack of cellular machinery left to save. Regenerating retinal cells is a futuristic prospect. A niche for gene therapy might be found in the treatment of congenital diseases. As one example, numerous successful pre-clinical studies led to clinical trials using AAV to deliver RPE65 for Leber congenital amaurosis (Bainbridge et al., 2015). Moreover, stem cell therapies may ultimately prove useful for replacing damaged retinal cells and tissues. For instance, recent efforts have elucidated a method of pharmacologically enhancing ciliogenesis in pluripotent stem 
cells perhaps providing a method to mature induced pluripotent stem cells for clinical application (May-Simera et al., 2018). All of these and other approaches will continue their development at various rates but it is possible to envision scenarios in which they will be combined to provide the best possible outcome based on prevention, protection, and replacement. Until that time, the technical, manufacturing and clinical progress achieved in cell encapsulation will provide a vanguard to overcome the therapeutic challenges unique to the eye and retina. 


\section{Legends}

Figure 1. Cell encapsulation, general concepts. This strategy is aimed at physically isolating a cell mass from an outside environment, within the boundaries of a semipermeable membrane. The membrane, in turn, protects the encapsulated cells against immune cell and antibody mediated rejection, while allowing the entrance of nutrients and oxygen, and the exit of therapeutic products into the surrounding tissue.

Figure 2. Private investment. Companies worldwide developing cell encapsulationbased biotechnology products.

Figure 3. Molecular cutoff of different types of microcapsule membranes. The molecular weights of various enzymes, antibodies, complement components, other proteins, peptides and metabolites are listed on the right. Abbreviations: C2-9 and C19, various components of the complement cascade; Ig, immunoglobulin; IL-1, interleukin 1; NGF, nerve growth factor; APA, alginate-poly-L-lysine/ornithine-alginate. Reproduced with permission from (Chang and Prakash, 1998).

Figure 4. Microcapsules. (A) APA microcapsules of $500 \mu \mathrm{m}$ diameter on a fingertip. (B-E) Highly monodisperse $100 \mu \mathrm{m}$ APA microcapsules: encapsulated cells showing an excellent cell viability (B). Microcapsules stained with Membrane Blue ${ }^{\circledR}$ in a total dose of $10 \mu \mathrm{L}(\mathrm{C})$ and subsequent retinography upon administration in the intravitreous space of rats, where encapsulated cells remained viable at least 3 weeks (E). (B-E) Reproduced with permission from (Santos et al., 2012).

Figure 5. Macroencapsulation device (Hollow Fiber). Schematic representation of the NsG0202.1 device. PET, polyethylene terephthalate. Reproduced with permission from (Eyjolfsdottir et al., 2016).

Figure 6. Retinal photomicrographs of transgenic rats carrying the rhodopsin mutation S334ter. (A) S334ter untreated eye, (B) NTC-200 parental cell-treated eye, and (C) NTC-201 cell-treated eye. Brackets denote ONL. Reproduced with permission from (Tao et al., 2002). 
Figure 7. NT-501 releases CNTF in the vitreous for at least 2-years in patients. (A) Photomicrographs of $\mathrm{H} \& \mathrm{E}$ stained histological sections of explanted devices. (B) CNTF levels detected in human vitreous over 6, 12, 18 and 24 months from high dose implants corresponding to explanted CNTF device secretion. Reproduced with permission from (Kauper et al., 2012).

Figure 8. Retinal and adaptive optics scanning laser ophthalmoscopy (AOSLO) images. For each patient, fundus photographs are shown with AOSLO images and foveal horizontal spectral-domain optical coherence tomography (OCT) scans superimposed (horizontal lines: OCT scan location; white squares on AOSLO images: ROIs where cone spacing was analyzed in each AOSLO image over 30 months; yellow squares: retinal locations of density examples shown in Fig. 2). (A) Sham-treated and CNTFtreated eyes of patient 1. (B) Sham-treated and CNTF-treated eyes of patient 2. Bilateral epiretinal membranes on OCT images. (C) CNTF-treated and sham-treated eyes of patient 3. No AOSLO images were acquired in the sham-treated eye of patient 3 because of severe cystoid macular edema and vitreous opacities (arrow points to opacity obscuring retinal detail). Reproduced with permission from (Talcott et al., 2011). 
Tables

Table 1

\begin{tabular}{|c|c|c|c|}
\hline Material/Device & Drug Delivered & $\begin{array}{l}\text { Duration } \\
\text { Delivery }\end{array}$ & Ref. \\
\hline PLA microparticles & TG-0054 & 3 months & (Shelke et al., 2011) \\
\hline PLGA microparticles & GDNF & $\begin{array}{l}11 \text { weeks in } \\
\text { vivo }\end{array}$ & $\begin{array}{l}\text { (Garcia-Caballero et } \\
\text { al., 2017) }\end{array}$ \\
\hline PLGA microparticles & Dexamethasone & 50 days & (Zhang et al., 2009) \\
\hline $\begin{array}{l}\text { PLA microparticles and } \\
\text { nanoparticles }\end{array}$ & Budesonide & 2 weeks & $\begin{array}{l}\text { (Kompella et al., } \\
\text { 2003) }\end{array}$ \\
\hline $\begin{array}{l}\text { PLA microparticles and } \\
\text { nanoparticles }\end{array}$ & $\begin{array}{l}\text { Triamcinolone } \\
\text { acetonide }\end{array}$ & 2 months & (Kadam et al., 2012) \\
\hline $\begin{array}{l}\text { PLGA } \\
\text { microparticles }\end{array}$ & Celecoxib & 14 days & $\begin{array}{l}\text { (Ayalasomayajula } \\
\text { and Kompella, 2005) }\end{array}$ \\
\hline $\begin{array}{l}\text { Polyesteramide } \\
\text { microspheres }\end{array}$ & Bevacizumab & $\begin{array}{l}2 \text { months } \\
\text { vivo }\end{array}$ & $\begin{array}{l}\text { (Yandrapu et al., } \\
\text { 2013) }\end{array}$ \\
\hline $\begin{array}{l}\text { PLA nanoparticles in } \\
\text { porous PLGA } \\
\text { microparticles }\end{array}$ & Bevacizuma & 2 months & $\begin{array}{l}\text { (Yandrapu et al., } \\
\text { 2013) }\end{array}$ \\
\hline $\begin{array}{l}\text { Hyaluronic acid/dextran- } \\
\text { based in situ hydrogel }\end{array}$ & Dexamethasone & $\begin{array}{l}3 \text { months in } \\
\text { vivo }\end{array}$ & $\begin{array}{l}\text { (Andres-Guerrero et } \\
\text { al., 2015) }\end{array}$ \\
\hline $\begin{array}{l}\text { Hyaluronic acid/dextran- } \\
\text { based in situ hydrogel }\end{array}$ & Bevacizumab & 6 months & (Yu et al., 2015) \\
\hline ESHU gel & Bevacizumab & 9 weeks & (Rauck et al., 2014) \\
\hline mPEG-PLGA gel & Bevacizumab & 1 month & (Hu et al., 2014) \\
\hline Silk hydrogels & Bevacizumab & 3 months & (Lovett et al., 2015) \\
\hline Collagen matrix & Cisplatin & 2 weeks & (Gilbert et al., 2003) \\
\hline Liposome & Ganciclovir & 43 days & $\begin{array}{l}\text { (Le Bourlais et al., } \\
\text { 1996) }\end{array}$ \\
\hline Liposome & Bevacizumab & 42 days & $\begin{array}{l}\text { (Abrishami et al., } \\
\text { 2009) }\end{array}$ \\
\hline $\begin{array}{l}\text { Retisert } \\
\text { (nonbiodegradable } \\
\text { implant, PVA implant) }\end{array}$ & $\begin{array}{l}\text { Fluocinolone } \\
\text { acetonide }\end{array}$ & 3 years & (Driot et al., 2004) \\
\hline $\begin{array}{l}\text { Iluvien } \\
\text { implant) }\end{array}$ & $\begin{array}{l}\text { Fluocinolone } \\
\text { acetonide }\end{array}$ & 3 years & (Sanford, 2013) \\
\hline
\end{tabular}




\section{ACCEPTED MANUSCRIPT}

Ozurdex (biodegradable Dexamethasone 6 months (Lee et al., 2010) implant with PLGA)

\begin{tabular}{|c|c|c|c|c|c|}
\hline $\begin{array}{l}\text { Nonbiodegradable device, } \\
\text { EVA copolymer }\end{array}$ & Betamethasone & 1 month & & $\begin{array}{l}\text { (Okabe } \\
\text { 2003b) }\end{array}$ & et \\
\hline $\begin{array}{l}\text { Biodegradable, } \\
\text { intrascleral implant }\end{array}$ & $\begin{array}{l}\text { Betamethasone } \\
\text { phosphate }\end{array}$ & 8 weeks & & $\begin{array}{l}\text { (Okabe } \\
\text { 2003a) }\end{array}$ & et \\
\hline $\begin{array}{l}\text { PLGA biodegradable } \\
\text { scleral plug }\end{array}$ & FK506 (tacrolimus) & $\begin{array}{l}\text { at least } \\
\text { weeks } \\
\text { uveitis } \\
\text { treatment) }\end{array}$ & $\begin{array}{r}6 \\
\text { (for }\end{array}$ & $\begin{array}{l}\text { (Sakurai } \\
\text { 2003) }\end{array}$ & et \\
\hline
\end{tabular}




\section{References}

Abrishami, M., Zarei-Ghanavati, S., Soroush, D., Rouhbakhsh, M., Jaafari, M.R., Malaekeh-Nikouei, B., 2009. Preparation, characterization, and in vivo evaluation of nanoliposomes-encapsulated bevacizumab (avastin) for intravitreal administration. Retina 29, 699-703.

AG, C., GLP-1 CellBeads® for the Treatment of Stroke Patients With Space-occupying Intracerebral Hemorrhage. . https://clinicaltrials.gov/ct2/show/NCT01298830. (accessed 13 February 2018).

Agulnick, A.D., Ambruzs, D.M., Moorman, M.A., Bhoumik, A., Cesario, R.M., Payne, J.K., Kelly, J.R., Haakmeester, C., Srijemac, R., Wilson, A.Z., Kerr, J., Frazier, M.A., Kroon, E.J., D'Amour, K.A., 2015. Insulin-Producing Endocrine Cells Differentiated In Vitro From Human Embryonic Stem Cells Function in Macroencapsulation Devices In Vivo. Stem Cells Transl Med 4, 1214-1222.

Akbari, S., Pirbodaghi, T., Kamm, R.D., Hammond, P.T., 2017. A versatile microfluidic device for high throughput production of microparticles and cell microencapsulation. Lab Chip 17, 2067-2075.

Andres-Guerrero, V., Zong, M., Ramsay, E., Rojas, B., Sarkhel, S., Gallego, B., de Hoz, R., Ramirez, A.I., Salazar, J.J., Trivino, A., Ramirez, J.M., Del Amo, E.M., Cameron, N., de-Las-Heras, B., Urtti, A., Mihov, G., Dias, A., Herrero-Vanrell, R., 2015. Novel biodegradable polyesteramide microspheres for controlled drug delivery in Ophthalmology. Journal of controlled release : official journal of the Controlled Release Society 211, 105-117.

Attia, N., Santos, E., Abdelmouty, H., Arafa, S., Zohdy, N., Hernandez, R.M., Orive, G., Pedraz, J.L., 2014. Behaviour and ultrastructure of human bone marrow-derived mesenchymal stem cells immobilised in alginate-poly-l-lysine-alginate microcapsules. J Microencapsul 31, 579-589.

Austrianova., http://www.austrianova.com/. (accessed 14 February 2018).

Awwad, S., Mohamed Ahmed, A.H.A., Sharma, G., Heng, J.S., Khaw, P.T., Brocchini, S., Lockwood, A., 2017. Principles of pharmacology in the eye. Br. J. Pharmacol. 174, 4205-4223.

Ayalasomayajula, S.P., Kompella, U.B., 2005. Subconjunctivally administered celecoxib-PLGA microparticles sustain retinal drug levels and alleviate diabetesinduced oxidative stress in a rat model. Eur. J. Pharmacol. 511, 191-198. 
Bainbridge, J.W., Mehat, M.S., Sundaram, V., Robbie, S.J., Barker, S.E., Ripamonti, C., Georgiadis, A., Mowat, F.M., Beattie, S.G., Gardner, P.J., Feathers, K.L., Luong, V.A., Yzer, S., Balaggan, K., Viswanathan, A., de Ravel, T.J., Casteels, I., Holder, G.E., Tyler, N., Fitzke, F.W., Weleber, R.G., Nardini, M., Moore, A.T., Thompson, D.A., Petersen-Jones, S.M., Michaelides, M., van den Born, L.I., Stockman, A., Smith, A.J., Rubin, G., Ali, R.R., 2015. Long-term effect of gene therapy on Leber's congenital amaurosis. N. Engl. J. Med. 372, 1887-1897.

Basta, G., Calafiore, R., 2011. Immunoisolation of pancreatic islet grafts with no recipient's immunosuppression: actual and future perspectives. Curr. Diab. Rep. 11, 384-391.

Basta, G., Montanucci, P., Luca, G., Boselli, C., Noya, G., Barbaro, B., Qi, M., Kinzer, K.P., Oberholzer, J., Calafiore, R., 2011. Long-term metabolic and immunological follow-up of nonimmunosuppressed patients with type 1 diabetes treated with microencapsulated islet allografts: four cases. Diabetes care 34, 2406-2409.

Bayer, C.L., Herrero, E.P., Peppas, N.A., 2011. Alginate films as macromolecular imprinted matrices. J. Biomater. Sci. Polym. Ed. 22, 1523-1534.

Benhar, I., London, A., Schwartz, M., 2012. The privileged immunity of immune privileged organs: the case of the eye. Front Immunol 3, 296.

Bertens, C.J.F., Gijs, M., van den Biggelaar, F., Nuijts, R., 2018. Topical drug delivery devices: A review. Exp. Eye Res. 168, 149-160.

Biotech., P., http://pharmacyte.com/. (accessed 14 February 2018).

Bok, D., Yasumura, D., Matthes, M.T., Ruiz, A., Duncan, J.L., Chappelow, A.V., Zolutukhin, S., Hauswirth, W., LaVail, M.M., 2002. Effects of adeno-associated virusvectored ciliary neurotrophic factor on retinal structure and function in mice with a P216L rds/peripherin mutation. Exp. Eye Res. 74, 719-735.

Calafiore, R., Basta, G., 2014. Clinical application of microencapsulated islets: actual prospectives on progress and challenges. Advanced drug delivery reviews 67-68, 84-92.

Catena, R., Santos, E., Orive, G., Hernandez, R.M., Pedraz, J.L., Calvo, A., 2010. Improvement of the monitoring and biosafety of encapsulated cells using the SFGNESTGL triple reporter system. Journal of controlled release : official journal of the Controlled Release Society 146, 93-98.

Cipitria, A., Salmeron-Sanchez, M., 2017. Mechanotransduction and Growth Factor Signalling to Engineer Cellular Microenvironments. Adv Healthc Mater 6. 
Cone, R.E., Chattopadhyay, S., O'Rourke, J., 2008. Control of delayed-type hypersensitivity by ocular- induced CD8+ regulatory t cells. Chem. Immunol. Allergy 94, 138-149.

Cornolti, R., Figliuzzi, M., Remuzzi, A., 2009. Effect of micro- and macroencapsulation on oxygen consumption by pancreatic islets. Cell Transplant. 18, 195-201.

Chan, E.-S., Lim, T.-K., Voo, W.-P., Pogaku, R., Tey, B.T., Zhang, Z., 2011. Effect of formulation of alginate beads on their mechanical behavior and stiffness. Particuology $9,228-234$.

Chang, T.M., 1964. SEMIPERMEABLE MICROCAPSULES. Science 146, 524-525.

Chang, T.M., 2005. Therapeutic applications of polymeric artificial cells. Nat Rev Drug Discov 4, 221-235.

Chang, T.M., Prakash, S., 1998. Therapeutic uses of microencapsulated genetically engineered cells. Mol. Med. Today 4, 221-227.

Chaudhuri, O., Gu, L., Klumpers, D., Darnell, M., Bencherif, S.A., Weaver, J.C., Huebsch, N., Lee, H.P., Lippens, E., Duda, G.N., Mooney, D.J., 2016. Hydrogels with tunable stress relaxation regulate stem cell fate and activity. Nat Mater 15, 326-334.

Dandoy, P., Meunier, C.F., Leroux, G., Voisin, V., Giordano, L., Caron, N., Michiels, C., Su, B.L., 2013. A hybrid assembly by encapsulation of human cells within mineralised beads for cell therapy. PLoS One 8, e54683.

De Castro, M., Orive, G., Hernandez, R.M., Gascon, A.R., Pedraz, J.L., 2005. Comparative study of microcapsules elaborated with three polycations (PLL, PDL, PLO) for cell immobilization. J. Microencapsul. 22, 303-315.

de Vos, P., Hamel, A.F., Tatarkiewicz, K., 2002. Considerations for successful transplantation of encapsulated pancreatic islets. Diabetologia 45, 159-173.

de Vos, P., Lazarjani, H.A., Poncelet, D., Faas, M.M., 2014. Polymers in cell encapsulation from an enveloped cell perspective. Advanced drug delivery reviews 67$68,15-34$.

Deglon, N., Heyd, B., Tan, S.A., Joseph, J.M., Zurn, A.D., Aebischer, P., 1996. Central nervous system delivery of recombinant ciliary neurotrophic factor by polymer encapsulated differentiated C2C12 myoblasts. Hum. Gene Ther. 7, 2135-2146. 
Del Amo, E.M., Rimpela, A.K., Heikkinen, E., Kari, O.K., Ramsay, E., Lajunen, T., Schmitt, M., Pelkonen, L., Bhattacharya, M., Richardson, D., Subrizi, A., Turunen, T., Reinisalo, M., Itkonen, J., Toropainen, E., Casteleijn, M., Kidron, H., Antopolsky, M., Vellonen, K.S., Ruponen, M., Urtti, A., 2017. Pharmacokinetic aspects of retinal drug delivery. Prog. Retin. Eye Res. 57, 134-185.

Desai, T., Shea, L.D., 2017. Advances in islet encapsulation technologies. Nat Rev Drug Discov 16, 338-350.

Driot, J.Y., Novack, G.D., Rittenhouse, K.D., Milazzo, C., Pearson, P.A., 2004. Ocular pharmacokinetics of fluocinolone acetonide after Retisert intravitreal implantation in rabbits over a 1-year period. J. Ocul. Pharmacol. Ther. 20, 269-275.

Elliott, R.B., Escobar, L., Tan, P.L., Muzina, M., Zwain, S., Buchanan, C., 2007. Live encapsulated porcine islets from a type 1 diabetic patient $9.5 \mathrm{yr}$ after xenotransplantation. Xenotransplantation 14, 157-161.

Emerich, D.F., Orive, G., Thanos, C., Tornoe, J., Wahlberg, L.U., 2014. Encapsulated cell therapy for neurodegenerative diseases: from promise to product. Adv Drug Deliv Rev 67-68, 131-141.

Eyjolfsdottir, H., Eriksdotter, M., Linderoth, B., Lind, G., Juliusson, B., Kusk, P., Almkvist, O., Andreasen, N., Blennow, K., Ferreira, D., Westman, E., Nennesmo, I., Karami, A., Darreh-Shori, T., Kadir, A., Nordberg, A., Sundstrom, E., Wahlund, L.O., Wall, A., Wiberg, M., Winblad, B., Seiger, A., Wahlberg, L., Almqvist, P., 2016. Targeted delivery of nerve growth factor to the cholinergic basal forebrain of Alzheimer's disease patients: application of a second-generation encapsulated cell biodelivery device. Alzheimers Res. Ther. 8, 30.

Forrester, J.V., Xu, H., Lambe, T., Cornall, R., 2008. Immune privilege or privileged immunity? Mucosal Immunol 1, 372-381.

Garcia-Caballero, C., Prieto-Calvo, E., Checa-Casalengua, P., Garcia-Martin, E., PoloLlorens, V., Garcia-Feijoo, J., Molina-Martinez, I.T., Bravo-Osuna, I., Herrero-Vanrell, R., 2017. Six month delivery of GDNF from PLGA/vitamin E biodegradable microspheres after intravitreal injection in rabbits. Eur J Pharm Sci 103, 19-26.

Gasperini, L., Mano, J.F., Reis, R.L., 2014. Natural polymers for the microencapsulation of cells. J R Soc Interface 11, 20140817.

Gattas-Asfura, K.M., Stabler, C.L., 2013. Bioorthogonal layer-by-layer encapsulation of pancreatic islets via hyperbranched polymers. ACS applied materials \& interfaces 5, 9964-9974. 
Gilbert, J.A., Simpson, A.E., Rudnick, D.E., Geroski, D.H., Aaberg, T.M., Jr., Edelhauser, H.F., 2003. Transscleral permeability and intraocular concentrations of cisplatin from a collagen matrix. J. Control. Release 89, 409-417.

Goldberg, J.L., NT-501 CNTF Implant for Glaucoma: Safety, Neuroprotection and Neuroenhancement. . https://clinicaltrials.gov/ct2/show/NCT01408472. (accessed 13 February 2018).

Gonzalez-Pujana, A., Rementeria, A., Blanco, F.J., Igartua, M., Pedraz, J.L., SantosVizcaino, E., Hernandez, R.M., 2017a. The role of osmolarity adjusting agents in the regulation of encapsulated cell behavior to provide a safer and more predictable delivery of therapeutics. Drug Deliv 24, 1654-1666.

Gonzalez-Pujana, A., Santos, E., Orive, G., Pedraz, J.L., Hernandez, R.M., 2017b. Cell microencapsulation technology: Current vision of its therapeutic potential through the administration routes. Journal of Drug Delivery Science and Technology 42, 49-62.

Goren, A., Dahan, N., Goren, E., Baruch, L., Machluf, M., 2010. Encapsulated human mesenchymal stem cells: a unique hypoimmunogenic platform for long-term cellular therapy. FASEB J 24, 22-31.

Gravastrand, C., Hamad, S., Fure, H., Steinkjer, B., Ryan, L., Oberholzer, J., Lambris, J.D., Lacik, I., Mollnes, T.E., Espevik, T., Brekke, O.L., Rokstad, A.M., 2017. Alginate microbeads are coagulation compatible, while alginate microcapsules activate coagulation secondary to complement or directly through FXII. Acta Biomater 58, 158167.

Guerrero-Naranjo, J.L., Quiroz-Mercado, H., Sanchez-Bermudez, G., Schoonewolff, F., Longoria, S.S., Vera, R.R., Tao, W., Beckman, R., Morales-Canton, V., 2013. Safety of implantation of the NT-503 device in patients with choroidal neovascularization secondary to age-related macular degeneration. Invest. Ophthalmol. Vis. Sci. 54, 32983298 .

Hashemi, M., Kalalinia, F., 2015. Application of encapsulation technology in stem cell therapy. Life Sci. 143, 139-146.

Heile, A., Brinker, T., 2011. Clinical translation of stem cell therapy in traumatic brain injury: the potential of encapsulated mesenchymal cell biodelivery of glucagon-like peptide-1. Dialogues Clin. Neurosci. 13, 279-286.

Hernandez, R.M., Orive, G., Murua, A., Pedraz, J.L., 2010. Microcapsules and microcarriers for in situ cell delivery. Adv Drug Deliv Rev 62, 711-730. 
Hu, C.C., Chaw, J.R., Chen, C.F., Liu, H.W., 2014. Controlled release bevacizumab in thermoresponsive hydrogel found to inhibit angiogenesis. Biomed. Mater. Eng. 24, 1941-1950.

Huebsch, N., Arany, P.R., Mao, A.S., Shvartsman, D., Ali, O.A., Bencherif, S.A., Rivera-Feliciano, J., Mooney, D.J., 2010. Harnessing traction-mediated manipulation of the cell/matrix interface to control stem-cell fate. Nat Mater 9, 518-526.

Hunt, N.C., Hallam, D., Karimi, A., Mellough, C.B., Chen, J., Steel, D.H.W., Lako, M., 2017. 3D culture of human pluripotent stem cells in RGD-alginate hydrogel improves retinal tissue development. Acta Biomater 49, 329-343.

Jiang, L.Q., Jorquera, M., Streilein, J.W., 1993. Subretinal space and vitreous cavity as immunologically privileged sites for retinal allografts. Invest. Ophthalmol. Vis. Sci. 34, 3347-3354.

Josephs, S.F., Loudovaris, T., Dixit, A., Young, S.K., Johnson, R.C., 1999. In vivo delivery of recombinant human growth hormone from genetically engineered human fibroblasts implanted within Baxter immunoisolation devices. J. Mol. Med. (Berl.) 77, 211-214.

Kadam, R.S., Tyagi, P., Edelhauser, H.F., Kompella, U.B., 2012. RETRACTED:

Influence of choroidal neovascularization and biodegradable polymeric particle size on transscleral sustained delivery of triamcinolone acetonide. Int. J. Pharm. 434, 140-147.

Kauper, K., McGovern, C., Sherman, S., Heatherton, P., Rapoza, R., Stabila, P., Dean, B., Lee, A., Borges, S., Bouchard, B., Tao, W., 2012. Two-year intraocular delivery of ciliary neurotrophic factor by encapsulated cell technology implants in patients with chronic retinal degenerative diseases. Investigative ophthalmology \& visual science 53, 7484-7491.

Kauper, K., Nystuen, A., 2017. 12 Cell Therapy for Ophthalmic Diseases. Cell Therapy: Current Status and Future Directions, 249.

Kezuka, T., Sakai, J., Usui, N., Streilein, J.W., Usui, M., 2001. Evidence for antigenspecific immune deviation in patients with acute retinal necrosis. Arch. Ophthalmol. 119, 1044-1049.

Kim, A.R., Hwang, J.H., Kim, H.M., Kim, H.N., Song, J.E., Yang, Y.I., Yoon, K.H., Lee, D., Khang, G., 2013. Reduction of inflammatory reaction in the use of purified alginate microcapsules. J. Biomater. Sci. Polym. Ed. 24, 1084-1098. 
Kleinschmidt, K., Klinge, P.M., Stopa, E., Wallrapp, C., Glage, S., Geigle, P., Brinker, T., 2011. Alginate encapsulated human mesenchymal stem cells suppress syngeneic glioma growth in the immunocompetent rat. J. Microencapsul. 28, 621-627.

Kompella, U.B., Bandi, N., Ayalasomayajula, S.P., 2003. Subconjunctival nano- and microparticles sustain retinal delivery of budesonide, a corticosteroid capable of inhibiting VEGF expression. Invest. Ophthalmol. Vis. Sci. 44, 1192-1201.

Korsgren, O., 2017. Islet Encapsulation: Physiological Possibilities and Limitations. Diabetes 66, 1748-1754.

Kumagai-Braesch, M., Jacobson, S., Mori, H., Jia, X., Takahashi, T., Wernerson, A., Flodstrom-Tullberg, M., Tibell, A., 2013. The TheraCyte device protects against islet allograft rejection in immunized hosts. Cell Transplant. 22, 1137-1146.

Lacik, I., Brissova, M., Anilkumar, A.V., Powers, A.C., Wang, T., 1998. New capsule with tailored properties for the encapsulation of living cells. J Biomed Mater Res 39, 52-60.

Lakhani, P., Patil, A., Majumdar, S., 2018. Recent advances in topical nano drugdelivery systems for the anterior ocular segment. Ther. Deliv. 9, 137-153.

Lathuiliere, A., Bohrmann, B., Kopetzki, E., Schweitzer, C., Jacobsen, H., Moniatte, M., Aebischer, P., Schneider, B.L., 2014a. Genetic engineering of cell lines using lentiviral vectors to achieve antibody secretion following encapsulated implantation. Biomaterials 35, 792-802.

Lathuiliere, A., Cosson, S., Lutolf, M.P., Schneider, B.L., Aebischer, P., 2014b. A highcapacity cell macroencapsulation system supporting the long-term survival of genetically engineered allogeneic cells. Biomaterials 35, 779-791.

Lathuiliere, A., Laversenne, V., Astolfo, A., Kopetzki, E., Jacobsen, H., Stampanoni, M., Bohrmann, B., Schneider, B.L., Aebischer, P., 2016. A subcutaneous cellular implant for passive immunization against amyloid-beta reduces brain amyloid and tau pathologies. Brain 139, 1587-1604.

Lathuiliere, A., Mach, N., Schneider, B.L., 2015. Encapsulated cellular implants for recombinant protein delivery and therapeutic modulation of the immune system. Int. J. Mol. Sci. 16, 10578-10600.

Le Bourlais, C., Chevanne, F., Ropert, P., Bretagne, G., Acar, L., Zia, H., Sado, P.A., Needham, T., Leverge, R., 1996. Release kinetics of liposome-encapsulated ganciclovir after intravitreal injection in rabbits. J. Microencapsul. 13, 473-480. 
Lee, K.Y., Mooney, D.J., 2012. Alginate: properties and biomedical applications. Progress in polymer science 37, 106-126.

Lee, S.S., Hughes, P., Ross, A.D., Robinson, M.R., 2010. Biodegradable implants for sustained drug release in the eye. Pharm. Res. 27, 2043-2053.

Li, R.H., Williams, S., Burkstrand, M., Roos, E., 2000. Encapsulation matrices for neurotrophic factor-secreting myoblast cells. Tissue Eng. 6, 151-163.

Liebmann, J.M., Cioffi, G.A., 2017. Nicking Glaucoma with Nicotinamide? N. Engl. J. Med. 376, 2079-2081.

Lim, F., Sun, A.M., 1980. Microencapsulated islets as bioartificial endocrine pancreas. Science 210, 908-910.

Limited, D.O., Open-label Investigation of the Safety and Effectiveness of DIABECELL(R) in Patients With Type I Diabetes Mellitus.

https://clinicaltrials.gov/ct2/show/NCT00940173. (accessed 13 February 2018).

Limited, D.O., Open-label Investigation of the Safety and Effectiveness of DIABECELL $®$ in Patients With Type 1 Diabetes Mellitus. .

https://clinicaltrials.gov/ct2/show/NCT01739829. (accessed 13 February 2018).

Liu, C., Li, Y., Peng, M., Laties, A.M., Wen, R., 1999. Activation of caspase-3 in the retina of transgenic rats with the rhodopsin mutation s334ter during photoreceptor degeneration. J. Neurosci. 19, 4778-4785.

Liu, Z., Takeuchi, M., Nakajima, M., Hu, C., Hasegawa, Y., Huang, Q., Fukuda, T., 2017. Three-dimensional hepatic lobule-like tissue constructs using cell-microcapsule technology. Acta Biomater 50, 178-187.

Lovett, M.L., Wang, X., Yucel, T., York, L., Keirstead, M., Haggerty, L., Kaplan, D.L., 2015. Silk hydrogels for sustained ocular delivery of anti-vascular endothelial growth factor (anti-VEGF) therapeutics. Eur. J. Pharm. Biopharm. 95, 271-278.

Ludwig, B., Rotem, A., Schmid, J., Weir, G.C., Colton, C.K., Brendel, M.D., Neufeld, T., Block, N.L., Yavriyants, K., Steffen, A., Ludwig, S., Chavakis, T., Reichel, A., Azarov, D., Zimermann, B., Maimon, S., Balyura, M., Rozenshtein, T., Shabtay, N., Vardi, P., Bloch, K., de Vos, P., Schally, A.V., Bornstein, S.R., Barkai, U., 2012. Improvement of islet function in a bioartificial pancreas by enhanced oxygen supply and growth hormone releasing hormone agonist. Proc. Natl. Acad. Sci. U. S. A. 109, 5022-5027. 
Luo, X.M., Lin, H., Wang, W., Geaney, M.S., Law, L., Wynyard, S., Shaikh, S.B., Waldvogel, H., Faull, R.L., Elliott, R.B., Skinner, S.J., Lee, J.E., Tan, P.L., 2013.

Recovery of neurological functions in non-human primate model of Parkinson's disease by transplantation of encapsulated neonatal porcine choroid plexus cells. J. Parkinsons Dis. 3, 275-291.

Lv, H., Li, L., Sun, M., Zhang, Y., Chen, L., Rong, Y., Li, Y., 2015. Mechanism of regulation of stem cell differentiation by matrix stiffness. Stem Cell. Res. Ther. 6, 103.

Llacua, L.A., de Haan, B.J., de Vos, P., 2018. Laminin and collagen IV inclusion in immunoisolating microcapsules reduces cytokine-mediated cell death in human pancreatic islets. J. Tissue Eng. Regen. Med. 12, 460-467.

Martin, D.F., 2018. Evolution of Intravitreal Therapy for Retinal Diseases-From CMV to CNV: The LXXIV Edward Jackson Memorial Lecture. Am. J. Ophthalmol.

May-Simera, H.L., Wan, Q., Jha, B.S., Hartford, J., Khristov, V., Dejene, R., Chang, J., Patnaik, S., Lu, Q., Banerjee, P., Silver, J., Insinna-Kettenhofen, C., Patel, D., Lotfi, M., Malicdan, M., Hotaling, N., Maminishkis, A., Sridharan, R., Brooks, B., Miyagishima, K., Gunay-Aygun, M., Pal, R., Westlake, C., Miller, S., Sharma, R., Bharti, K., 2018. Primary Cilium-Mediated Retinal Pigment Epithelium Maturation Is Disrupted in Ciliopathy Patient Cells. Cell Rep 22, 189-205.

Mazumder, M.A., Burke, N.A., Shen, F., Potter, M.A., Stover, H.D., 2009. Core-crosslinked alginate microcapsules for cell encapsulation. Biomacromolecules 10, 13651373.

Mead, B., Berry, M., Logan, A., Scott, R.A., Leadbeater, W., Scheven, B.A., 2015. Stem cell treatment of degenerative eye disease. Stem Cell Res 14, 243-257.

Murua, A., de Castro, M., Orive, G., Hernandez, R.M., Pedraz, J.L., 2007. In vitro characterization and in vivo functionality of erythropoietin-secreting cells immobilized in alginate-poly-L-lysine-alginate microcapsules. Biomacromolecules 8, 3302-3307.

Nakaoka, R., Hirano, Y., Mooney, D.J., Tsuchiya, T., Matsuoka, A., 2013. Study on the potential of RGD- and PHSRN-modified alginates as artificial extracellular matrices for engineering bone. J Artif Organs 16, 284-293.

Neufeld, T., Ludwig, B., Barkai, U., Weir, G.C., Colton, C.K., Evron, Y., Balyura, M., Yavriyants, K., Zimermann, B., Azarov, D., Maimon, S., Shabtay, N., Rozenshtein, T., Lorber, D., Steffen, A., Willenz, U., Bloch, K., Vardi, P., Taube, R., de Vos, P., Lewis, E.C., Bornstein, S.R., Rotem, A., 2013. The efficacy of an immunoisolating membrane system for islet xenotransplantation in minipigs. PloS one 8, e70150. 
Neurotech., http://www.neurotechusa.com/. (accessed 14 February 2018).

Niederkorn, J.Y., 2002. Immune privilege in the anterior chamber of the eye. Crit. Rev. Immunol. 22, 13-46.

Niederkorn, J.Y., 2003. Mechanisms of immune privilege in the eye and hair follicle. J. Investig. Dermatol. Symp. Proc. 8, 168-172.

Niederkorn, J.Y., 2006a. See no evil, hear no evil, do no evil: the lessons of immune privilege. Nat. Immunol. 7, 354-359.

Niederkorn, J.Y., 2006b. See no evil, hear no evil, do no evil: the lessons of immune privilege. Nature immunology 7, 354.

No da, Y., Jeong, G.S., Lee, S.H., 2014. Immune-protected xenogeneic bioartificial livers with liver-specific microarchitecture and hydrogel-encapsulated cells. Biomaterials 35, 8983-8991.

Nussenblatt, R.B., Liu, B., Wei, L., Sen, H.N., 2013. The immunological basis of degenerative diseases of the eye. Int Rev Immunol 32, 97-112.

Okabe, J., Kimura, H., Kunou, N., Okabe, K., Kato, A., Ogura, Y., 2003a. Biodegradable intrascleral implant for sustained intraocular delivery of betamethasone phosphate. Invest. Ophthalmol. Vis. Sci. 44, 740-744.

Okabe, K., Kimura, H., Okabe, J., Kato, A., Kunou, N., Ogura, Y., 2003b. Intraocular tissue distribution of betamethasone after intrascleral administration using a nonbiodegradable sustained drug delivery device. Invest. Ophthalmol. Vis. Sci. 44, 27022707.

Olabisi, R.M., 2015. Cell microencapsulation with synthetic polymers. J Biomed Mater Res A 103, 846-859.

Orive, G., Ali, O.A., Anitua, E., Pedraz, J.L., Emerich, D.F., 2010. Biomaterial-based technologies for brain anti-cancer therapeutics and imaging. Biochim. Biophys. Acta 1806, 96-107.

Orive, G., Anitua, E., Pedraz, J.L., Emerich, D.F., 2009. Biomaterials for promoting brain protection, repair and regeneration. Nat. Rev. Neurosci. 10, 682-692. 
Orive, G., Emerich, D., De Vos, P., 2014a. Encapsulate this: the do's and don'ts. Nat. Med. 20, 233.

Orive, G., Hernandez, R.M., Gascon, A.R., Igartua, M., Rojas, A., Pedraz, J.L., 2001. Microencapsulation of an anti-VE-cadherin antibody secreting 1B5 hybridoma cells. Biotechnol. Bioeng. 76, 285-294.

Orive, G., Santos, E., Pedraz, J.L., Hernandez, R.M., 2014b. Application of cell encapsulation for controlled delivery of biological therapeutics. Advanced drug delivery reviews 67-68, 3-14.

Orning, P., Hoem, K.S., Coron, A.E., Skjak-Braek, G., Mollnes, T.E., Brekke, O.L., Espevik, T., Rokstad, A.M., 2016. Alginate microsphere compositions dictate different mechanisms of complement activation with consequences for cytokine release and leukocyte activation. J. Control. Release 229, 58-69.

Paredes Juarez, G.A., Spasojevic, M., Faas, M.M., de Vos, P., 2014. Immunological and technical considerations in application of alginate-based microencapsulation systems. Frontiers in bioengineering and biotechnology 2, 26.

Peppas, N.A., Bures, P., Leobandung, W., Ichikawa, H., 2000. Hydrogels in pharmaceutical formulations. Eur. J. Pharm. Biopharm. 50, 27-46.

Peppas, N.A., Hilt, J.Z., Khademhosseini, A., Langer, R., 2006. Hydrogels in biology and medicine: from molecular principles to bionanotechnology. Advanced materials 18, $1345-1360$.

Peppas, N.A., Keys, K.B., Torres-Lugo, M., Lowman, A.M., 1999. Poly(ethylene glycol)-containing hydrogels in drug delivery. J. Control. Release 62, 81-87.

Perez, V.L., Caspi, R.R., 2015. Immune mechanisms in inflammatory and degenerative eye disease. Trends Immunol 36, 354-363.

Perez, V.L., Saeed, A.M., Tan, Y., Urbieta, M., Cruz-Guilloty, F., 2013. The eye: A window to the soul of the immune system. J Autoimmun 45, 7-14.

Pharmaceuticals, N., Ciliary Neurotrophic Factor (CNTF) Safety Trial in Patients With Macular Telangiectasia (Mactel). https://clinicaltrials.gov/ct2/show/NCT01327911. (accessed 13 February 2018). 
Pharmaceuticals, N., A Phase 2 Multicenter Randomized Clinical Trial of CNTF for MacTel. . https://clinicaltrials.gov/ct2/show/NCT01949324. (accessed 13 February 2018).

Pharmaceuticals, N., A Study of an Encapsulated Cell Technology (ECT) Implant for Patients With Atrophic Macular Degeneration.

https://clinicaltrials.gov/ct2/show/NCT00447954. (accessed 13 February 2018).

Pharmaceuticals, N., A Study of Encapsulated Cell Technology (ECT) Implant for Participants With Early Stage Retinitis Pigmentosa. . https://clinicaltrials.gov/ct2/show/NCT00447980 (accessed 13 February 2018).

Rauck, B.M., Friberg, T.R., Medina Mendez, C.A., Park, D., Shah, V., Bilonick, R.A., Wang, Y., 2014. Biocompatible reverse thermal gel sustains the release of intravitreal bevacizumab in vivo. Invest. Ophthalmol. Vis. Sci. 55, 469-476.

Read, T.A., Sorensen, D.R., Mahesparan, R., Enger, P.O., Timpl, R., Olsen, B.R., Hjelstuen, M.H., Haraldseth, O., Bjerkvig, R., 2001. Local endostatin treatment of gliomas administered by microencapsulated producer cells. Nat. Biotechnol. 19, 29-34.

Rhee, K.D., Nusinowitz, S., Chao, K., Yu, F., Bok, D., Yang, X.J., 2013. CNTFmediated protection of photoreceptors requires initial activation of the cytokine receptor gp130 in Muller glial cells. Proc. Natl. Acad. Sci. U. S. A. 110, E4520-4529.

Rokstad, A.M., Brekke, O.L., Steinkjer, B., Ryan, L., Kollarikova, G., Strand, B.L., Skjak-Braek, G., Lacik, I., Espevik, T., Mollnes, T.E., 2011. Alginate microbeads are complement compatible, in contrast to polycation containing microcapsules, as revealed in a human whole blood model. Acta Biomater 7, 2566-2578.

Rokstad, A.M., Lacik, I., de Vos, P., Strand, B.L., 2014. Advances in biocompatibility and physico-chemical characterization of microspheres for cell encapsulation. Advanced drug delivery reviews 67-68, 111-130.

Sakurai, E., Nozaki, M., Okabe, K., Kunou, N., Kimura, H., Ogura, Y., 2003. Scleral plug of biodegradable polymers containing tacrolimus (FK506) for experimental uveitis. Invest. Ophthalmol. Vis. Sci. 44, 4845-4852.

Sanford, M., 2013. Fluocinolone acetonide intravitreal implant (Iluvien(R)): in diabetic macular oedema. Drugs 73, 187-193.

Santos, E., Garate, A., Pedraz, J.L., Orive, G., Hernandez, R.M., 2014. The synergistic effects of the RGD density and the microenvironment on the behavior of encapsulated 
cells: in vitro and in vivo direct comparative study. J Biomed Mater Res A 102, 3965 3972.

Santos, E., Larzabal, L., Calvo, A., Orive, G., Pedraz, J.L., Hernandez, R.M., $2013 a$. Inactivation of encapsulated cells and their therapeutic effects by means of TGL triplefusion reporter/biosafety gene. Biomaterials 34, 1442-1451.

Santos, E., Orive, G., Calvo, A., Catena, R., Fernandez-Robredo, P., Layana, A.G., Hernandez, R.M., Pedraz, J.L., 2012. Optimization of 100 mum alginate-poly-L-lysinealginate capsules for intravitreous administration. Journal of controlled release : official journal of the Controlled Release Society 158, 443-450.

Santos, E., Pedraz, J.L., Hernandez, R.M., Orive, G., 2013b. Therapeutic cell encapsulation: ten steps towards clinical translation. J. Control. Release 170, 1-14.

Schwenter, F., Zarei, S., Luy, P., Padrun, V., Bouche, N., Lee, J.S., Mulligan, R.C., Morel, P., Mach, N., 2011. Cell encapsulation technology as a novel strategy for human anti-tumor immunotherapy. Cancer Gene Ther. 18, 553-562.

Shelke, N.B., Kadam, R., Tyagi, P., Rao, V.R., Kompella, U.B., 2011. Intravitreal Poly(L-lactide) Microparticles Sustain Retinal and Choroidal Delivery of TG-0054, a Hydrophilic Drug Intended for Neovascular Diseases. Drug Deliv Transl Res 1, 76-90.

Shoichet, M.S., Winn, S.R., 2000. Cell delivery to the central nervous system. Adv Drug Deliv Rev 42, 81-102.

Shpak, A.A., Guekht, A.B., Druzhkova, T.A., Kozlova, K.I., Gulyaeva, N.V., 2017. Ciliary neurotrophic factor in patients with primary open-angle glaucoma and agerelated cataract. Mol. Vis. 23, 799-809.

Sieving, P.A., Caruso, R.C., Tao, W., Coleman, H.R., Thompson, D.J., Fullmer, K.R., Bush, R.A., 2006. Ciliary neurotrophic factor (CNTF) for human retinal degeneration: phase I trial of CNTF delivered by encapsulated cell intraocular implants. Proc. Natl. Acad. Sci. U. S. A. 103, 3896-3901.

Simo, G., Fernandez-Fernandez, E., Vila-Crespo, J., Ruiperez, V., Rodriguez-Nogales, J.M., 2017. Research progress in coating techniques of alginate gel polymer for cell encapsulation. Carbohydr Polym 170, 1-14.

Singh, P., Parashuram, K., Maurya, S., Ray, P., Reddy, A., 2012. Structureperformance-fouling studies of polysulfone microfiltration hollow fibre membranes. Bulletin of Materials Science 35, 817-822. 
Skinner, S.J., Geaney, M.S., Lin, H., Muzina, M., Anal, A.K., Elliott, R.B., Tan, P.L., 2009. Encapsulated living choroid plexus cells: potential long-term treatments for central nervous system disease and trauma. J Neural Eng 6, 065001.

Song, W., Lu, Y.C., Frankel, A.S., An, D., Schwartz, R.E., Ma, M., 2015. Engraftment of human induced pluripotent stem cell-derived hepatocytes in immunocompetent mice via 3D co-aggregation and encapsulation. Sci. Rep. 5, 16884.

Stein-Streilein, J., Streilein, J.W., 2002. Anterior chamber associated immune deviation (ACAID): regulation, biological relevance, and implications for therapy. Int. Rev.

Immunol. 21, 123-152.

Talcott, K.E., Ratnam, K., Sundquist, S.M., Lucero, A.S., Lujan, B.J., Tao, W., Porco, T.C., Roorda, A., Duncan, J.L., 2011. Longitudinal study of cone photoreceptors during retinal degeneration and in response to ciliary neurotrophic factor treatment. Invest.

Ophthalmol. Vis. Sci. 52, 2219-2226.

Tam, S.K., Bilodeau, S., Dusseault, J., Langlois, G., Halle, J.P., Yahia, L.H., 2011. Biocompatibility and physicochemical characteristics of alginate-polycation microcapsules. Acta Biomater 7, 1683-1692.

Tao, W., Wen, R., Goddard, M.B., Sherman, S.D., O'Rourke, P.J., Stabila, P.F., Bell, W.J., Dean, B.J., Kauper, K.A., Budz, V.A., Tsiaras, W.G., Acland, G.M., PearceKelling, S., Laties, A.M., Aguirre, G.D., 2002. Encapsulated cell-based delivery of CNTF reduces photoreceptor degeneration in animal models of retinitis pigmentosa. Invest. Ophthalmol. Vis. Sci. 43, 3292-3298.

Taylor, A.W., 2016. Ocular Immune Privilege and Transplantation. Front. Immunol. 7, 37.

Technologies, L.C., Investigation of the Safety and Efficacy of NTCELL® [Immunoprotected (Alginate-Encapsulated) Porcine Choroid Plexus Cells for Xenotransplantation] in Patients With Parkinson's Disease. . https://clinicaltrials.gov/ct2/show/NCT02683629. (accessed 13 February 2018).

Technologies, L.C., Open-label Investigation of the Safety and Clinical Effects of NTCELL in Patients With Parkinson's Disease. . https://clinicaltrials.gov/ct2/show/NCT01734733. (accessed 13 February 2018).

Technologies, L.C., Open-label Investigation of the Safety and Efficacy of DIABECELL in Patients With Type 1 Diabetes Mellitus. . https://clinicaltrials.gov/ct2/show/NCT01736228. (accessed 13 February 2018). 
Technologies., L.C., http://www.lctglobal.com/. (accessed 14 February 2018).

Tomei, A.A., Manzoli, V., Fraker, C.A., Giraldo, J., Velluto, D., Najjar, M., Pileggi, A., Molano, R.D., Ricordi, C., Stabler, C.L., Hubbell, J.A., 2014. Device design and materials optimization of conformal coating for islets of Langerhans. Proceedings of the National Academy of Sciences of the United States of America 111, 10514-10519.

Trappmann, B., Gautrot, J.E., Connelly, J.T., Strange, D.G., Li, Y., Oyen, M.L., Cohen Stuart, M.A., Boehm, H., Li, B., Vogel, V., Spatz, J.P., Watt, F.M., Huck, W.T., 2012. Extracellular-matrix tethering regulates stem-cell fate. Nat Mater 11, 642-649.

Tuch, B.E., Hughes, T.C., Evans, M.D., 2011. Encapsulated pancreatic progenitors derived from human embryonic stem cells as a therapy for insulin-dependent diabetes. Diabetes Metab. Res. Rev. 27, 928-932.

Tuch, B.E., Keogh, G.W., Williams, L.J., Wu, W., Foster, J.L., Vaithilingam, V., Philips, R., 2009. Safety and viability of microencapsulated human islets transplanted into diabetic humans. Diabetes care 32, 1887-1889.

Uludag, H., De Vos, P., Tresco, P.A., 2000. Technology of mammalian cell encapsulation. Adv Drug Deliv Rev 42, 29-64.

Urtti, A., 2006. Challenges and obstacles of ocular pharmacokinetics and drug delivery. Adv Drug Deliv Rev 58, 1131-1135.

Vegas, A.J., Veiseh, O., Doloff, J.C., Ma, M., Tam, H.H., Bratlie, K., Li, J., Bader, A.R., Langan, E., Olejnik, K., Fenton, P., Kang, J.W., Hollister-Locke, J., Bochenek, M.A., Chiu, A., Siebert, S., Tang, K., Jhunjhunwala, S., Aresta-Dasilva, S., Dholakia, N., Thakrar, R., Vietti, T., Chen, M., Cohen, J., Siniakowicz, K., Qi, M., McGarrigle, J., Graham, A.C., Lyle, S., Harlan, D.M., Greiner, D.L., Oberholzer, J., Weir, G.C., Langer, R., Anderson, D.G., 2016a. Combinatorial hydrogel library enables identification of materials that mitigate the foreign body response in primates. Nat. Biotechnol. 34, 345-352.

Vegas, A.J., Veiseh, O., Gurtler, M., Millman, J.R., Pagliuca, F.W., Bader, A.R., Doloff, J.C., Li, J., Chen, M., Olejnik, K., Tam, H.H., Jhunjhunwala, S., Langan, E., Aresta-Dasilva, S., Gandham, S., McGarrigle, J.J., Bochenek, M.A., Hollister-Lock, J., Oberholzer, J., Greiner, D.L., Weir, G.C., Melton, D.A., Langer, R., Anderson, D.G., 2016b. Long-term glycemic control using polymer-encapsulated human stem cellderived beta cells in immune-competent mice. Nat. Med. 22, 306-311.

Vermonden, T., Fedorovich, N.E., van Geemen, D., Alblas, J., van Nostrum, C.F., Dhert, W.J., Hennink, W.E., 2008. Photopolymerized thermosensitive hydrogels: synthesis, degradation, and cytocompatibility. Biomacromolecules 9, 919-926. 
Viacyte., http://viacyte.com/. (accessed 14 February 2018).

Waite, D., Wang, Y., Jones, D., Stitt, A., Raj Singh, T.R., 2017. Posterior drug delivery via periocular route: challenges and opportunities. Ther. Deliv. 8, 685-699.

Walters, N.J., Gentleman, E., 2015. Evolving insights in cell-matrix interactions: elucidating how non-soluble properties of the extracellular niche direct stem cell fate. Acta Biomater 11, 3-16.

Wang, T., Lacik, I., Brissova, M., Anilkumar, A.V., Prokop, A., Hunkeler, D., Green, R., Shahrokhi, K., Powers, A.C., 1997. An encapsulation system for the immunoisolation of pancreatic islets. Nat Biotechnol 15, 358-362.

Wilson, J.L., Najia, M.A., Saeed, R., McDevitt, T.C., 2014. Alginate encapsulation parameters influence the differentiation of microencapsulated embryonic stem cell aggregates. Biotechnology and bioengineering 111, 618-631.

Wilson, J.T., Cui, W., Kozlovskaya, V., Kharlampieva, E., Pan, D., Qu, Z., Krishnamurthy, V.R., Mets, J., Kumar, V., Wen, J., Song, Y., Tsukruk, V.V., Chaikof, E.L., 2011. Cell surface engineering with polyelectrolyte multilayer thin films. Journal of the American Chemical Society 133, 7054-7064.

Yandrapu, S.K., Upadhyay, A.K., Petrash, J.M., Kompella, U.B., 2013. Nanoparticles in porous microparticles prepared by supercritical infusion and pressure quench technology for sustained delivery of bevacizumab. Mol Pharm 10, 4676-4686.

Yu, J., Du, K.T., Fang, Q., Gu, Y., Mihardja, S.S., Sievers, R.E., Wu, J.C., Lee, R.J., 2010. The use of human mesenchymal stem cells encapsulated in RGD modified alginate microspheres in the repair of myocardial infarction in the rat. Biomaterials 31 , 7012-7020.

Yu, Y., Lau, L.C., Lo, A.C., Chau, Y., 2015. Injectable Chemically Crosslinked Hydrogel for the Controlled Release of Bevacizumab in Vitreous: A 6-Month In Vivo Study. Transl Vis Sci Technol 4, 5.

Zanin, M.P., Pettingill, L.N., Harvey, A.R., Emerich, D.F., Thanos, C.G., Shepherd, R.K., 2012. The development of encapsulated cell technologies as therapies for neurological and sensory diseases. J. Control. Release 160, 3-13.

Zanotti, L., Sarukhan, A., Dander, E., Castor, M., Cibella, J., Soldani, C., Trovato, A.E., Ploia, C., Luca, G., Calvitti, M., Mancuso, F., Arato, I., Golemac, M., Jonjic, N., Biondi, A., Calafiore, R., Locati, M., D'Amico, G., Viola, A., 2013. Encapsulated mesenchymal stem cells for in vivo immunomodulation. Leukemia 27, 500-503. 
Zhang, K., Hopkins, J.J., Heier, J.S., Birch, D.G., Halperin, L.S., Albini, T.A., Brown, D.M., Jaffe, G.J., Tao, W., Williams, G.A., 2011. Ciliary neurotrophic factor delivered by encapsulated cell intraocular implants for treatment of geographic atrophy in agerelated macular degeneration. Proc. Natl. Acad. Sci. U. S. A. 108, 6241-6245.

Zhang, L., Li, Y., Zhang, C., Wang, Y., Song, C., 2009. Pharmacokinetics and tolerance study of intravitreal injection of dexamethasone-loaded nanoparticles in rabbits. Int $\mathbf{J}$ Nanomedicine 4, 175-183. 
Box 1.

Box 1. Traditional routes of ocular drug delivery

Systemic delivery: Oral or intravenous administration can be used for ocular delivery but is typically not advised sue to peripheral degradation, poor bioavailability across blood-retinal barriers, and the need to deliver high drug concentrations to achieve therapeutic levels. Systemic delivery is a generally poor choice for larger, polar, unstable proteins and perptides.

Topical delivery: Topical administration of eye drops is the most common, patient complaint, and least invasive route of drug delivery. Traditional methods include emulsions, ointments and suspensions which may be used to improve several drug characteristics including solubility and bioavailability. Emulsions are generally oil-water or water-oil formulations. Suspensions consist of generally insoluble particles in solvent-based media. Drug action duration is dependent on particle size in these systems. Ointments improve drug duration and bioavailability by mixing a drug with a hydrocarbon like paraffin that melts at physiological temperatures. Thermosensitive gels such as ReGel can also be administered

Direct injection: Direct injections of drugs permits delivery directly to the posterior segment but typically only achieves short duration benefits due to drug washout and clearance. Chronic administration is difficult as repeated injections are associated with retinal detachment, bleeding, cataract formation and inflammation. The refinement of microneedles may overcome some of these issues by minimizing tissue damage and allowing deposition into specific compartments such as the sclera. Thermosensitive gels such as ReGel can be manufactured such that gelation occurs at physiological temperatures. The gels provide longer duration action, require less frequent administration that other drops and have improved bioavailablity

Implants: These systems are designed for direct ocular placement and can be formulated as either biodegradable or non-degradable systems. While requiring an invasive procedure these systems overcome the need for repeated injections and provide long-term, sustained delivery. Non-degradable systems may require removal after the drug is delivered making this approach expensive and cumbersome for the patient. The additional procedure also raises the risk of adverse events. It is notable though that several implants have been approved for use including Vitrasert, Retisert, Surodex, and Ozurdex. Although not an implant in the traditional sense, contact lens can be formulated with drugs by soaking them prior to placement or coating them with particles.

Nanotechnology: Recent developments in nanotechnology have permitted exploration of a number of drug formulations that use very small particles including nanomicelles, nanosuspensions, liposomes, nanoparticles, and dendrimers. These nano-formulations can be used as gels or ointments and their small size makes them well-tolerated, with decreased washout, improved bioavailability, and good biocompatibility. Particles size and bioadherance are important considerations when attempting to minimize clearance.

Implantable living cells: Cell therapy can, in principle, be used to repair or replace damaged ocular tissues. Stem cells can be derived from embryonic sources or can be "induced" to form appropriate cells to replace (for instance) retinal cells. On the otherhand, cells can be modified to secrete and deliver potentially efficacious molecules including proteins and peptides. The cells can be delivered with or without a matrix where they secrete the desired factor in a longterm, sustained fashion. Encapsulating the cells in an immunoisolatory device allows for a range of cells types to be used without concern of rejection. Moreover, the cells can be retrieved 


\section{Box 2: Ideal requirements for cell-based devices}

Biocompatible: The external components of the device including the membrane, adhesive that forms any seals, and any external tethering or handles for implantation and retrievable must be biocompatible. Refinements in materials engineering and the use of medical grade, easily curable glues have produced devices that elicit negligible fibrosis, cellular ingrowth, or protein adsorption.

Implantable and retrievable: The devices must be minimally invasive and compatible with current surgical techniques. The devices should also be easily retrievable if needed or desired. Hollow fiber devices such as those use by Neurotech, inc. have been clinically verified to be easily implantable and retrievable even after several years in life.

Non-animal, human cell sources: Early encapsulation studies focused on the use of animal-derived, uncontrolled dividing tissues (e.g fibroblasts) that would typically overgrow the device and form accumulating necrotic tissue that impaired both cell viability and membrane diffusion. Even the use of terminally differentiated cell lines was found to be unreliable and uncontrollable. Today, human derived cells such as ARPE-19 (and perhaps stem cells in the near future) are being used with reduced immunogenicity (as they are allogeneic), improved long-term viability and protein delivery (at least 5.5 years to date in the eye), excellent safety records in both eye and CNS compartments, and good compatibility with genetic engineering techniques.

Compatible with membrane scaffolding: The survival and function of encapsulated cells is highly dependent on the type of extracellular matrix scaffolding used within the devices. This scaffolding serves to immobilize cells, prevent aggregation and necrosis, and control cell morphology. Different cell types prefer different scaffolding with ARPE-19 cells preferring PET yarn and chromaffin cells preferring alginate (as 2 examples).

Molecular techniques permitting high and controllable dosing: Early studies in animals demonstrated that primary cells were insufficient at producing reasonable levels of secreted agents. While the feasibility of delivering proteins and other molecules from modified cells was evident it was also clear that higher factor secretion would be needed to enable adequate distribution and dosing. Today's molecular techniques (such as the Sleeping Beauty transposon system used by Gloriana Therapeutics) yield stable gene transfer with secretion approaching log order increases over that achieved with earlier techniques.

Manufacturable: Each of the requirements listed above need to be achieved under controllable and scalable processes. All device components should be sourced and tested under GMP conditions. Refinements in semi-automated robotically-assisted manufacture and cell-loading will serve to continuously improve performance and consistency. 


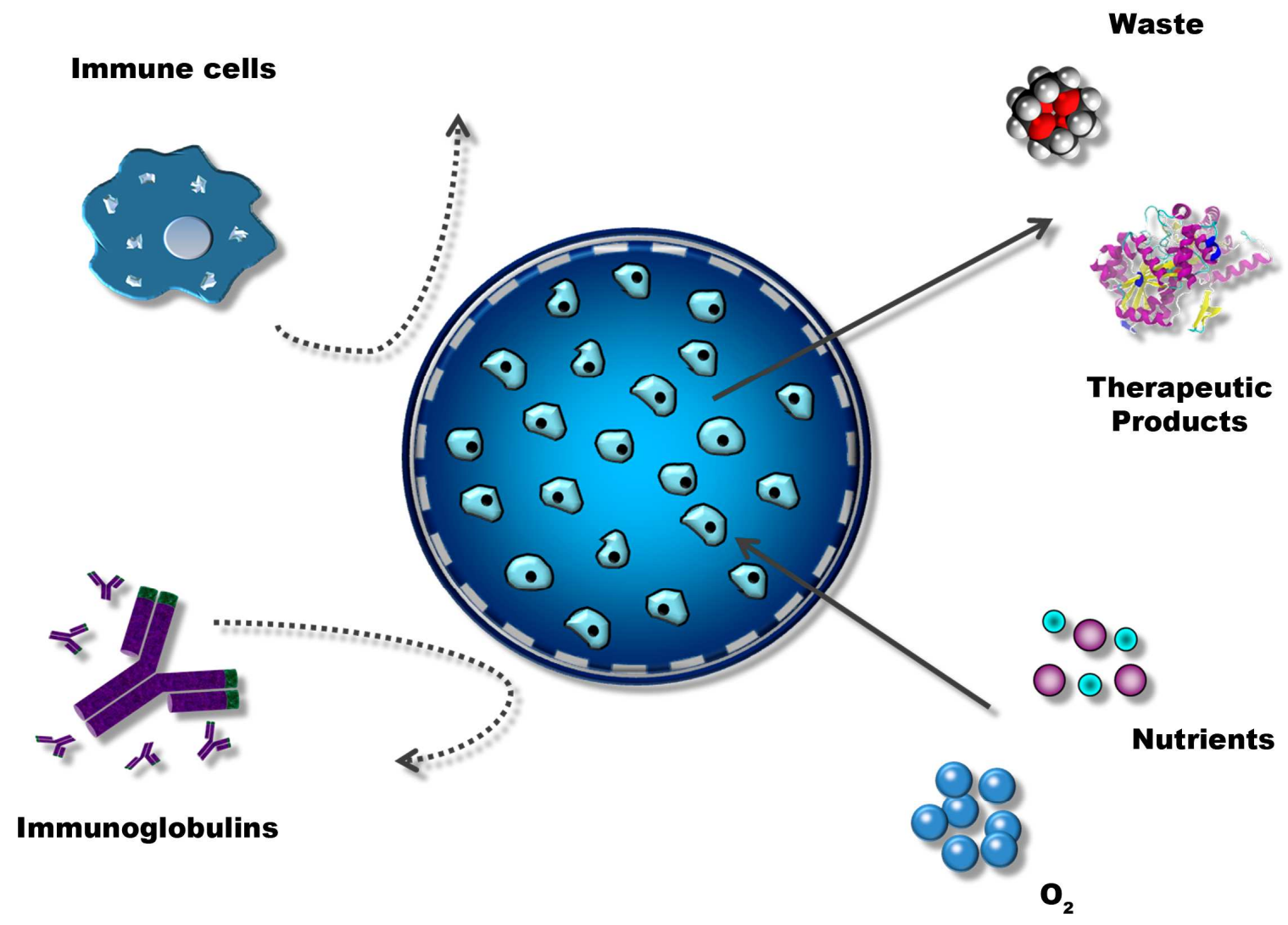




\begin{tabular}{|c|c|c|c|c|}
\hline Company & Country & Main application & Technology & Current research status \\
\hline $\begin{array}{l}\text { Semma } \\
\text { Therapeutics }\end{array}$ & USA & $\begin{array}{l}\text { Pluripotent stem cell-derived pancreatic Beta } \\
\text { cells for diabetes }\end{array}$ & Under development & Preclinical stage \\
\hline Sernova & Canada & Islets combined with Sertoli cells for diabetes & Cell Pouch System ${ }^{\mathrm{TM}}$ & $\begin{array}{l}\text { Conducting a Phase } 1 / 2 \text { clinical study in } \\
\text { subjects with diabetes }\end{array}$ \\
\hline \multirow[t]{3}{*}{ Neurotech } & \multirow[t]{3}{*}{ USA } & \multirow[t]{3}{*}{$\begin{array}{l}\text { Genetically modified cells for ophthalmic } \\
\text { diseases such as MacTel and glaucoma }\end{array}$} & \multirow[t]{3}{*}{ Encapsulated Cell Therapy (ECT) } & $\begin{array}{l}\text { NT- } 501 \text { for MacTel - Positive Phase } 2 \\
\text { results reported }\end{array}$ \\
\hline & & & & NT-501 for glaucoma - Phase 2 \\
\hline & & & & $\begin{array}{l}\text { NT-503 for Wet AMD - Phase } 2 \text { program } \\
\text { discontinued }\end{array}$ \\
\hline \multirow[t]{2}{*}{ Pharmacyte } & \multirow[t]{2}{*}{ USA } & \multirow[t]{2}{*}{$\begin{array}{l}\text { Ifosfamide-activating cells for cancer and insulin- } \\
\text { producing genetically engineered human liver } \\
\text { cells "Melligen" for diabetes }\end{array}$} & \multirow[t]{2}{*}{ Cell-in-a-Box® } & $\begin{array}{l}\text { Reduced tumor size with no obvious } \\
\text { adverse side effects in Phase } 1 / 2 \text { clinical } \\
\text { study for pancreatic cancer }\end{array}$ \\
\hline & & & & Preclinical stage for diabetes \\
\hline Viacyte & USA & $\begin{array}{l}\text { Differentiation of stem cells into pancreatic Beta } \\
\text { cell precursors (PEC- } 01^{\mathrm{TM}} \text { ) for diabetes }\end{array}$ & Encaptra® & $\begin{array}{l}\text { Encouraging observations for PEC-Encap }{ }^{\mathrm{TM}} \\
\text { (or VC- } 01^{\mathrm{TM}} \text { ) in Phase } 1 / 2 \text { clinical trials }\end{array}$ \\
\hline Encapsulife & USA & Pancreatic Beta cells for diabetes & $\begin{array}{l}\text { Multi-component membrane capsule } \\
\text { system based on PMCG-CS /CACL2- } \\
\text { Alginate membrane }\end{array}$ & Successful trials in primates \\
\hline \multirow{2}{*}{$\begin{array}{l}\text { Gloriana } \\
\text { Therapeutics } \\
\text { (former NsGene) }\end{array}$} & \multirow[t]{2}{*}{ USA } & \multirow[t]{2}{*}{ Genetically modified cells for AD and PD } & \multirow[t]{2}{*}{ Encapsulated Cell technology (EC) } & $\begin{array}{l}\text { Safe and long-lasting ( } 6-12 \text { months) Phase } \\
1 \mathrm{~b} \text { trial with EC-NGF product for } A D\end{array}$ \\
\hline & & & & $\begin{array}{l}\text { EC-GDNF program for PD in preclinical } \\
\text { development }\end{array}$ \\
\hline
\end{tabular}




\begin{tabular}{|c|c|c|c|c|}
\hline $\begin{array}{l}\text { Living Cell } \\
\text { Technologies }\end{array}$ & $\begin{array}{l}\text { New Zealand, } \\
\text { Australia }\end{array}$ & Choroid plexus epithelial cells for PD & IMMUPEL TM & $\begin{array}{l}\text { Statistically significant improvement with } \\
\text { NTCELL } \AA \text { for PD in the Phase } 2 b \text { study }\end{array}$ \\
\hline $\begin{array}{l}\text { BetaO2 } \\
\text { Technologies }\end{array}$ & Israel & Pancreatic Beta cells for diabetes & $\beta$ Air Bio-artificial Pancreas & $\begin{array}{l}\text { Demonstrated safety with limited islet } \\
\text { function shown by } \beta \text { Air Bio-artificial } \\
\text { Pancreas in Phase } 1 \text { study }\end{array}$ \\
\hline AustriaNova & Singapore & GMP encapsulation services & Cell-in-a-Box® & \\
\hline
\end{tabular}




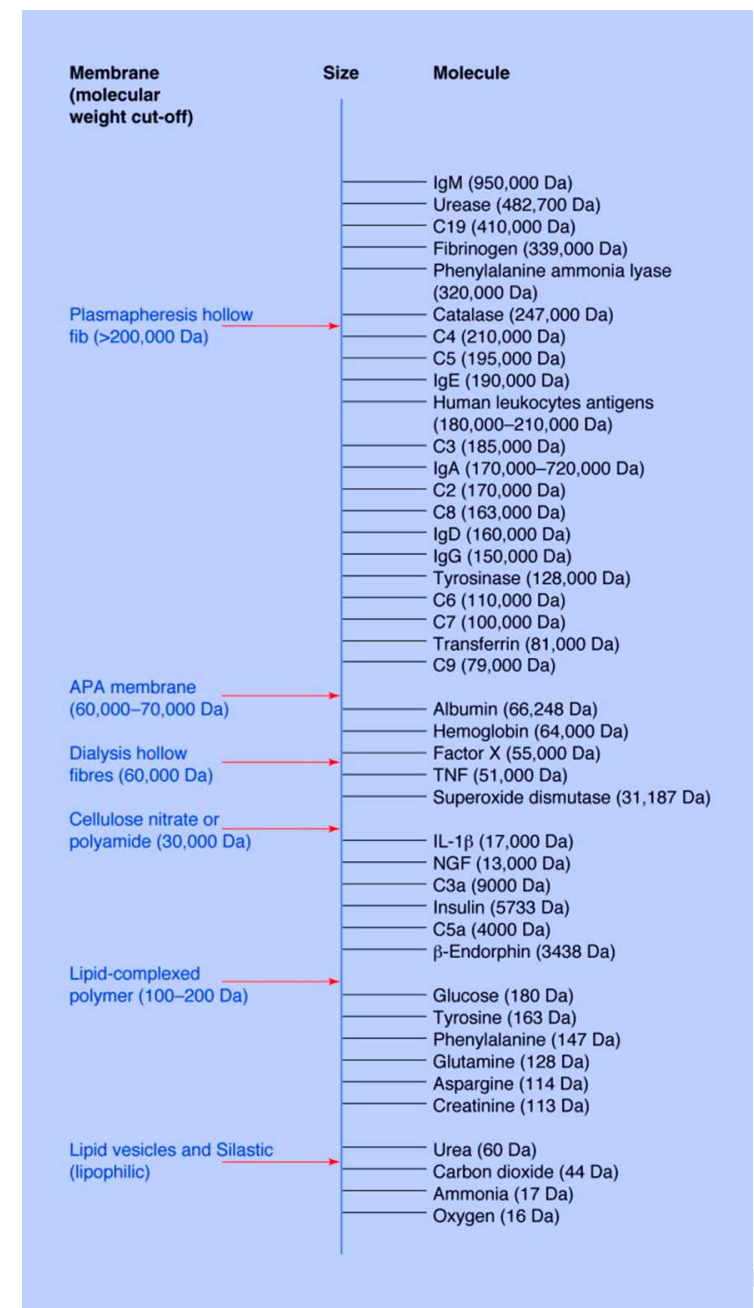




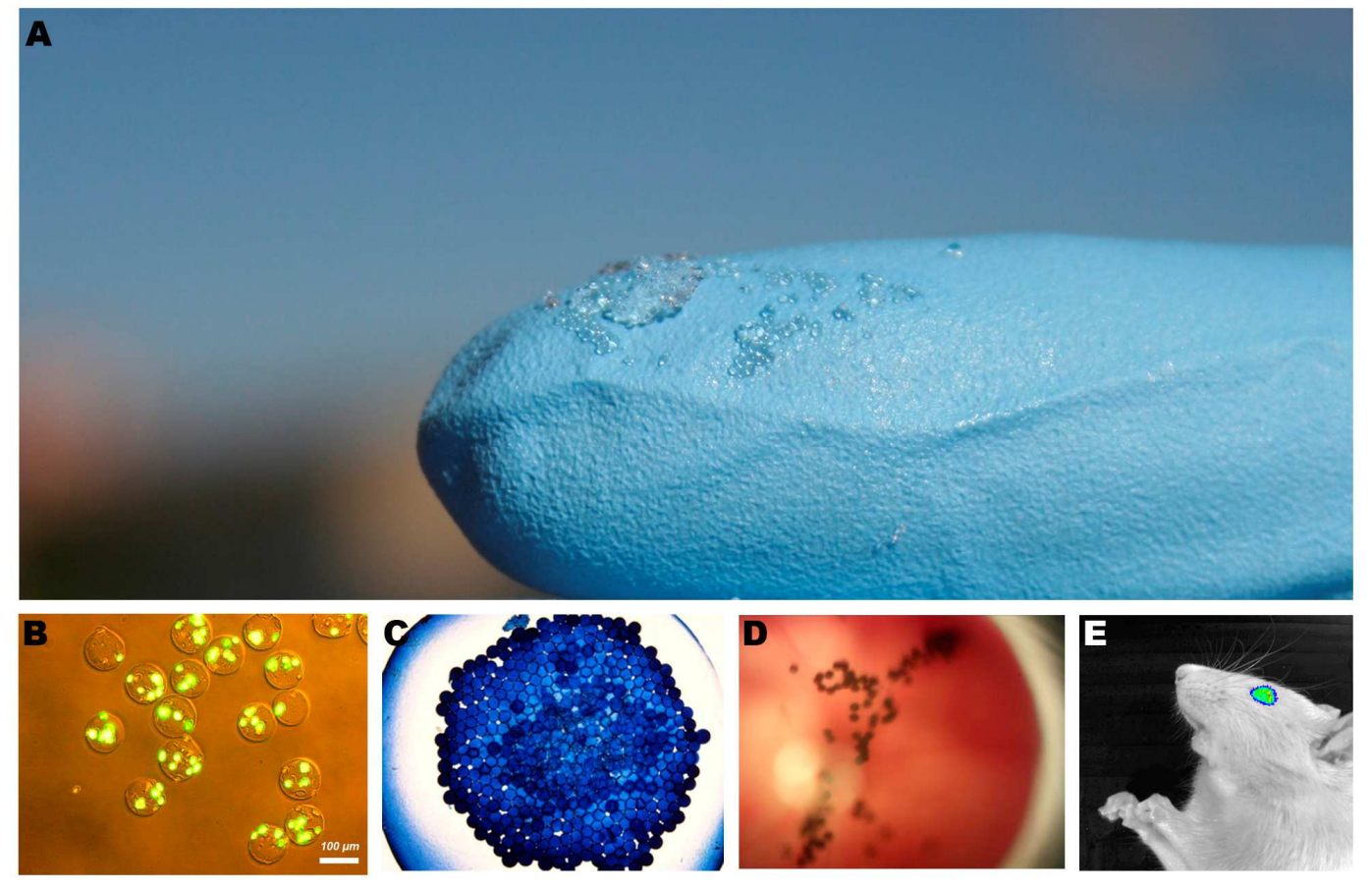




\section{Cells}

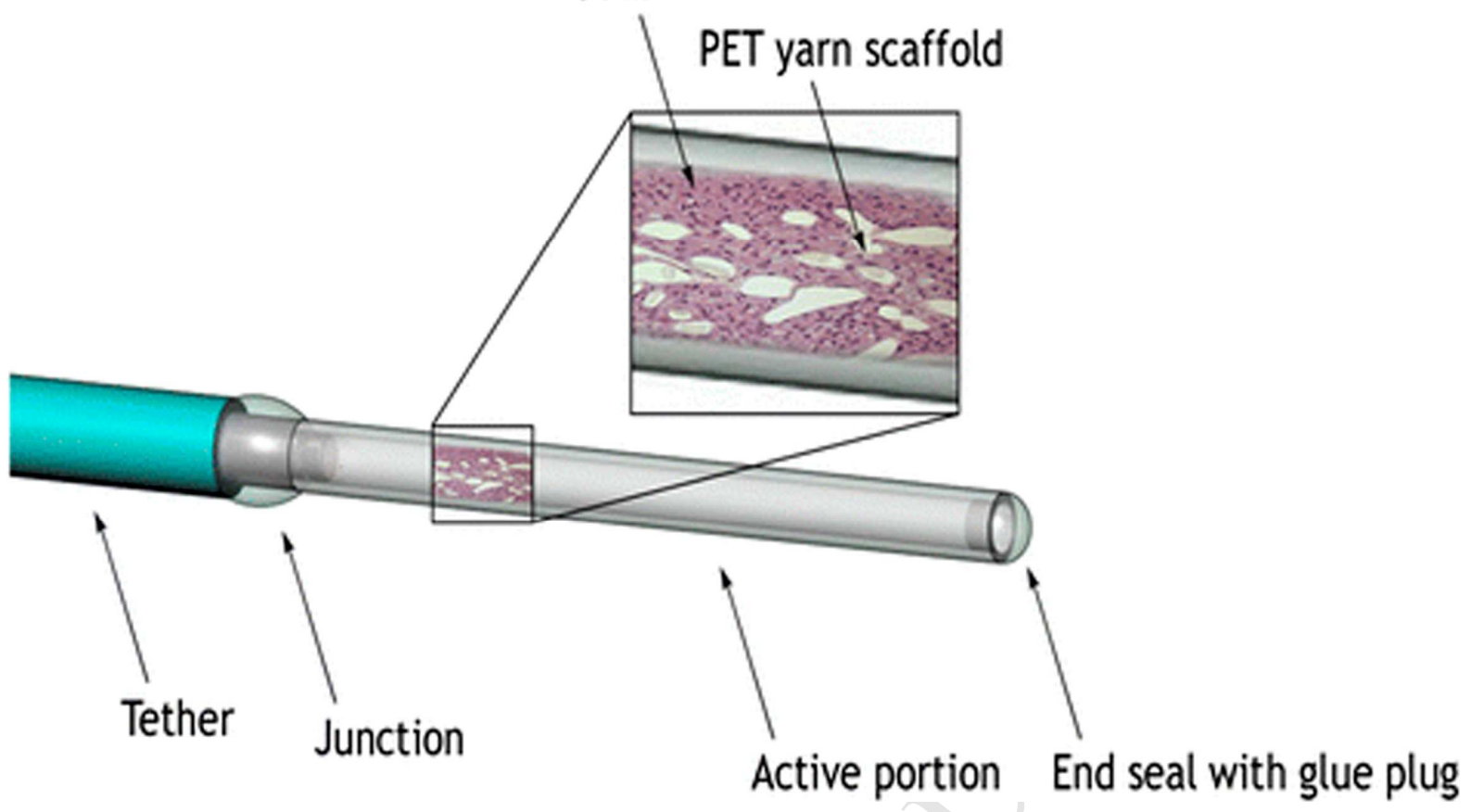




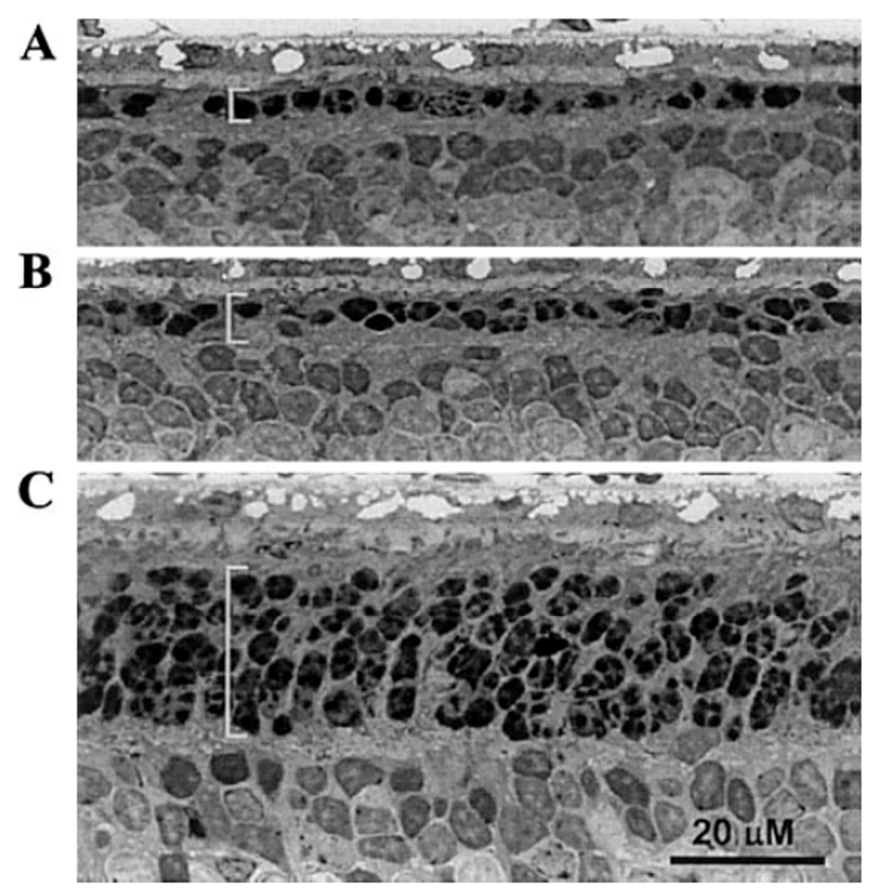




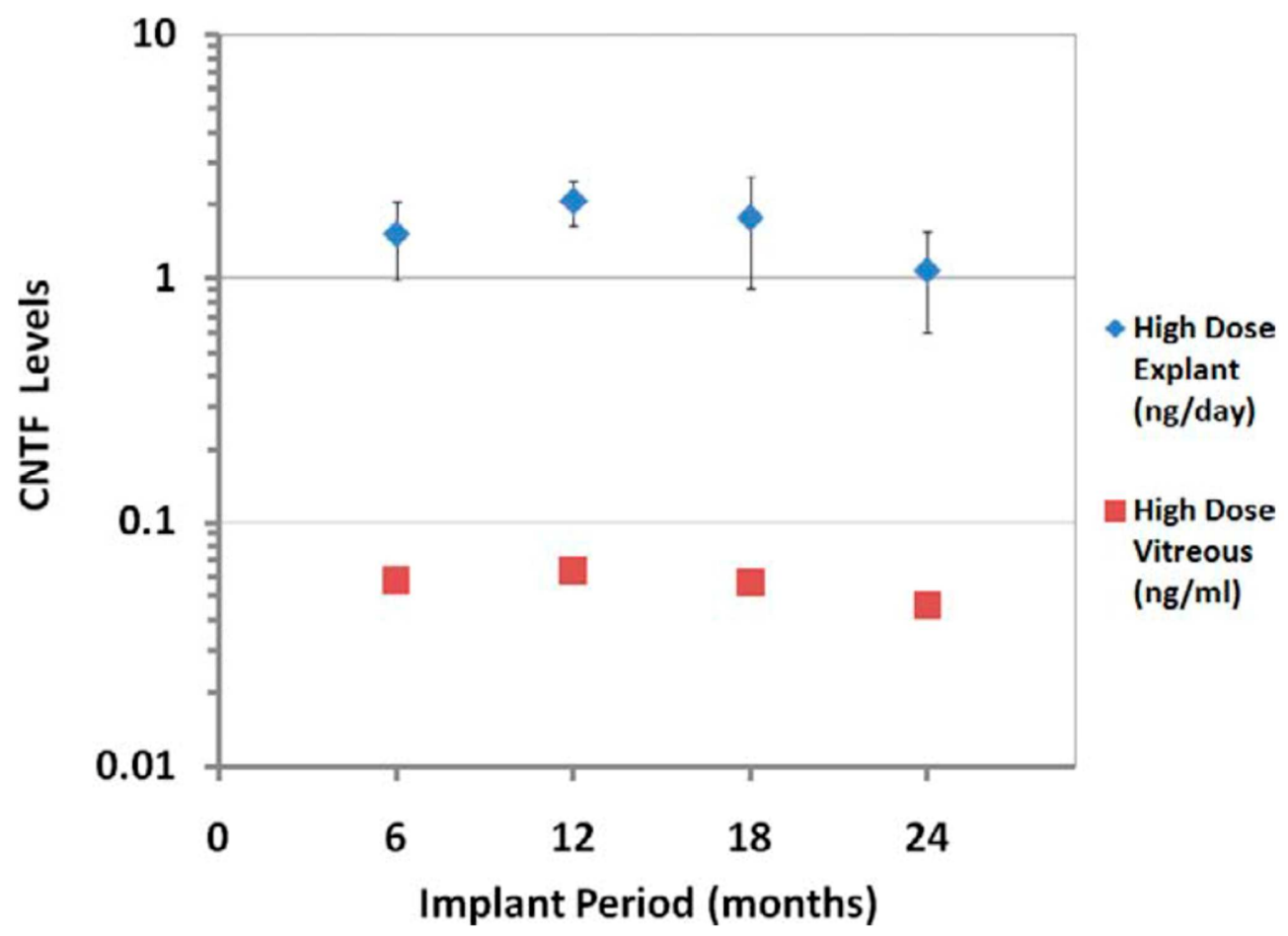



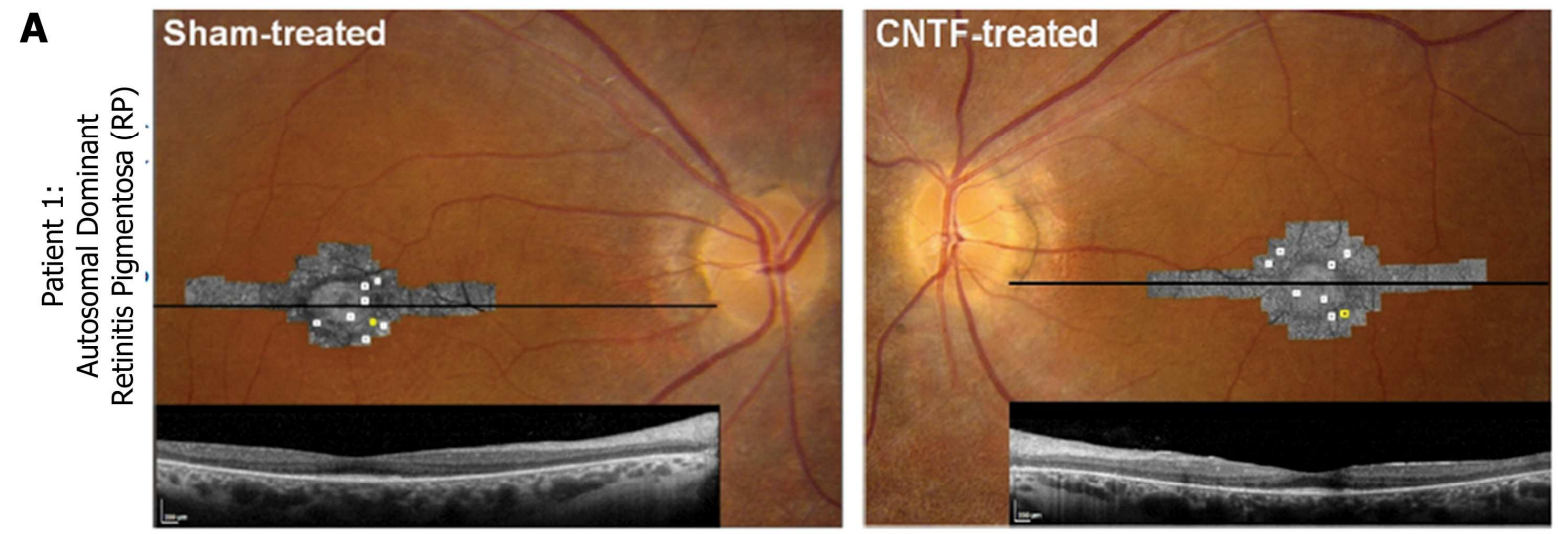

B
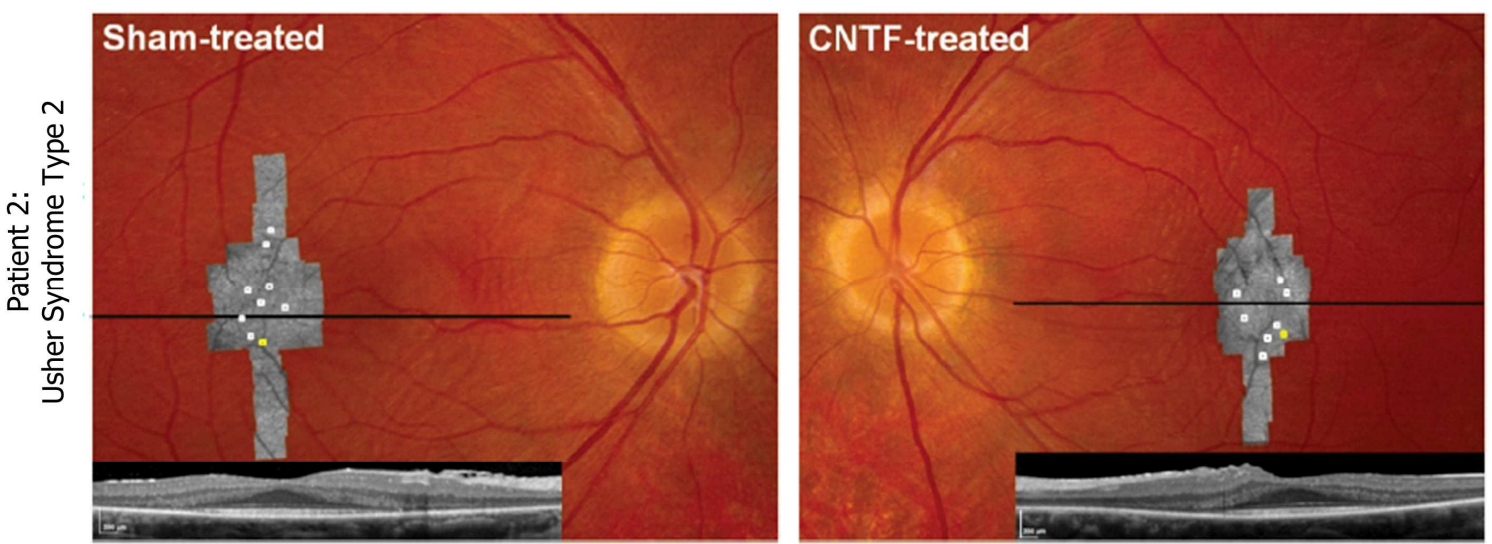

C
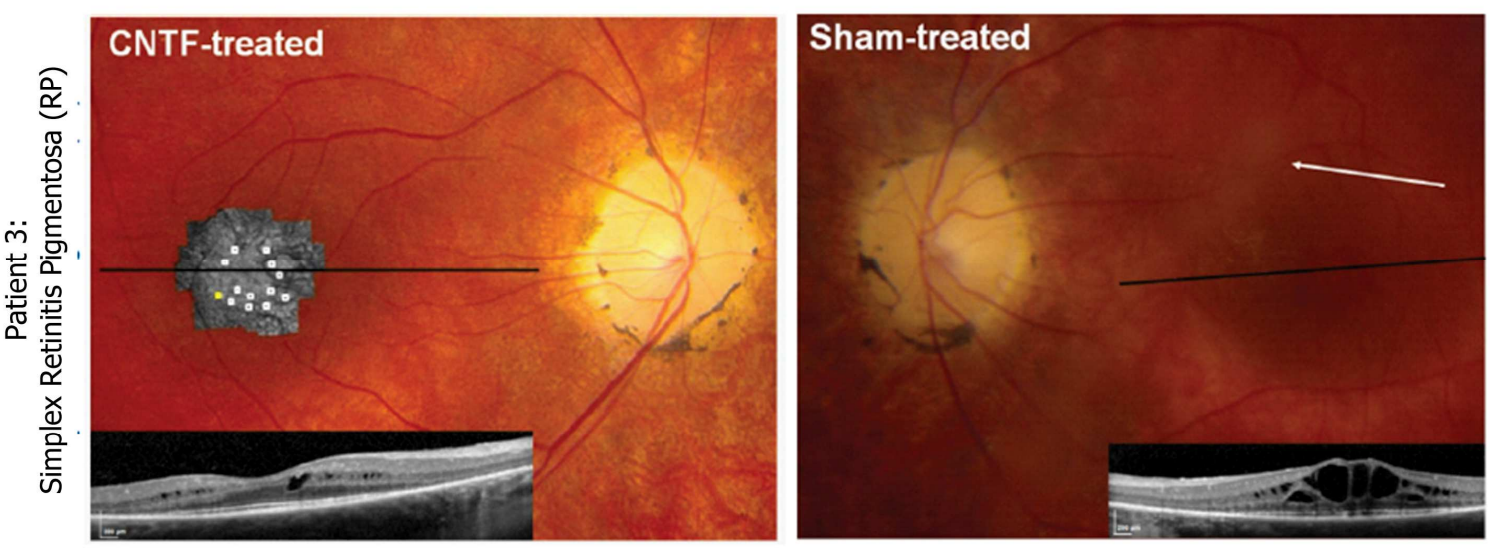


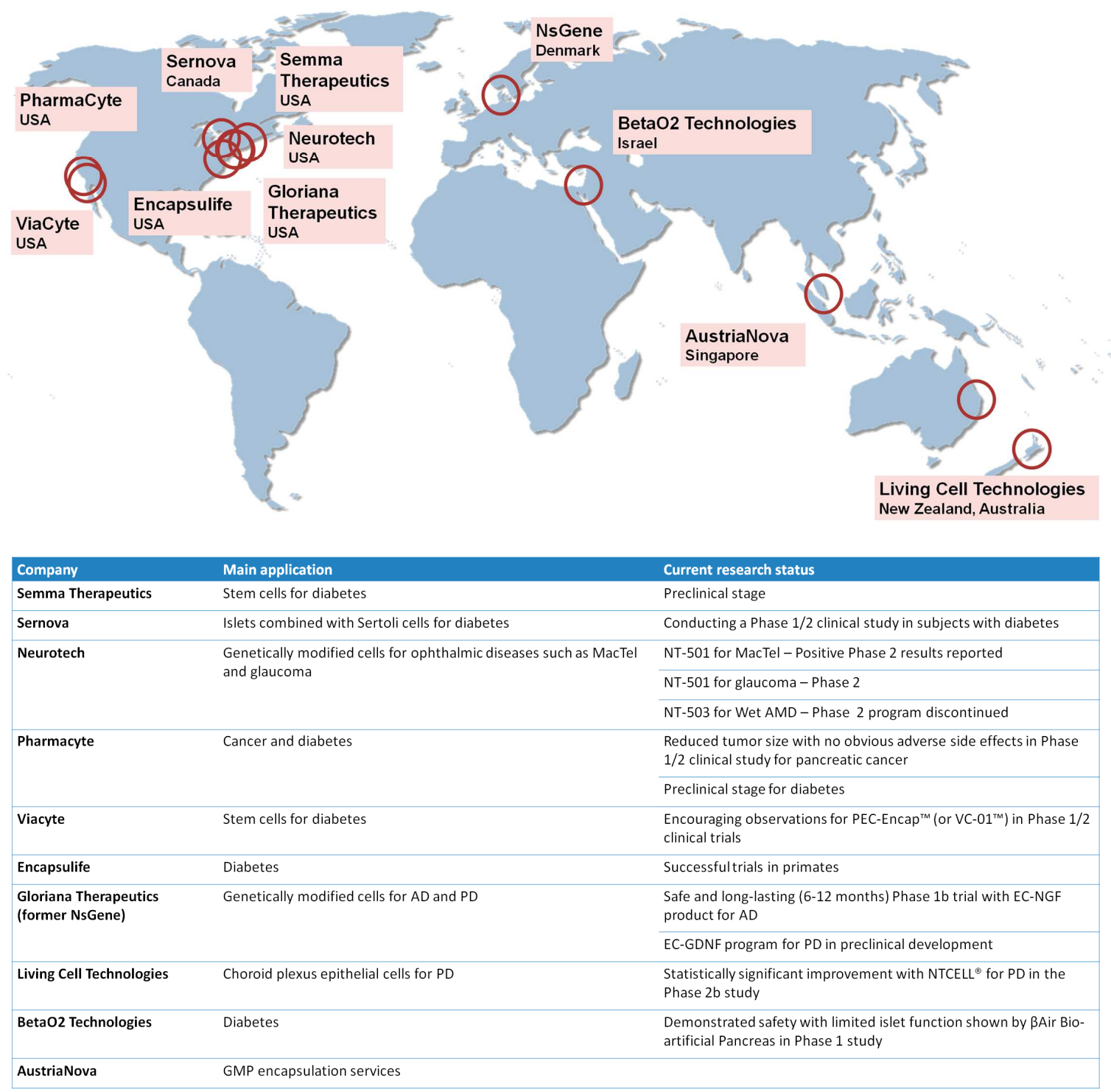

